\title{
PINTOR OU DESIGNER POPULAR: A ETNOGRAFIA DE UM OFÍCIO ATRAVÉS DO ACERVO DE EDSON MEIRELLES
}

Suiá Omim (1) $ه$

Universidade Federal do Tocantins I Porto Nacional - TO -Brasil 


\section{RESUMO}

Edson Meirelles, fotógrafo e pesquisador carioca, confeccionou um acervo fotográfico composto por mais de 20 mil cromos entre 1971 e 2004, cujo principal objetivo é alavancar uma vasta documentação de expressões pictóricas populares, coletadas em diferentes cidades do Brasil. A categoria pintor ou designer popular foi utilizada por Meirelles para descrever uma atividade manual de pintura, que - embora heterogênea nas formas, propósitos e usos nas diferentes regiões do Brasil contemporâneo - delimita um ofício específico, envolvendo técnicas, talentos, conhecimentos e reconhecimentos, distinguindo-o de outras atividades, como a de pintor de paredes ou de quadros, de artista plástico, de designer ou de artista gráfico. O presente artigo propõe-se a realizar uma etnografia dos textos escritos por Meirelles sobre as especificidades e as diversidades dessas atividades que configuram o ofício de pintor ou designer popular.

Palavras-chave: pintor ou designer popular; acerco fotográfico; memória social

\section{POPULAR PAINTER OR DESIGNER: THE ETHNOGRAPHY OF A CRAFT THROUGH THE COLLECTION OF EDSON MEIRELLES}

\section{ABSTRACT}

Edson Meirelles, a photographer and researcher from Rio de Janeiro, organized a photographic collection composed of more than 20 thousand chromes from 1971 to 2004, which main goal was to leverage a vast documentation of popular pictorial expressions collected around different Brazilian cities. The category of popular painter or designer was used by Meirelles in order to describe a manual painting activity which - despite being heterogeneous in its forms, purposes and uses in the different regions of contemporary Brazil - outlines a specific craft, involving techniques, talents, knowledges and recognitions, which distinguishes itself from other activities such as painter of walls or frames, plastic artist, designer or graphic artist. The purpose of this paper is to carry out an ethnography of the texts written by Meirelles on the specificities and the diversities of those activities that constitute the craft of a popular painter or designer.

Keywords: painter or popular designer; photographic collection; social memory

\section{PINTOR O DISEÑADOR POPULAR: LA ETNOGRAFÍA DE UN OFICIO A TRAVÉS DEL ACERVO DE EDSON MEIRELLES}

\section{RESUMEN}

Edson Meirelles, fotógrafo e investigador carioca, confeccionó un acervo fotográfico compuesto por más de 20 mil cromos entre 1971 y 2004, cuyo principal objetivo es impulsionar una vasta documentación de expresiones pictóricas populares recogidas en diferentes ciudades de Brasil. La categoría pintor o diseñador popular fue utilizada por Meirelles para describir una actividad manual de pintura que -aunque heterogénea en sus formas, propósitos y usos en las diferentes regiones del Brasil contemporáneo- delimita un oficio específico, que incluye técnicas, talentos, conocimientos y reconocimientos, que lo distingue de otros oficios como el pintor de paredes, el pintor de cuadros, el artista plástico, el diseñador, el artista gráfico. El presente artículo se propone realizar una etnografía de los textos escritos por Meirelles sobre las especificidades y diversidades de estas actividades que configuran el oficio de pintor o diseñador popular.

Palabras clave: pintor o diseñador popular: acervo fotográfico; memoria social 
[...] um pintor de tetos e tabuletas, que levou a fantasia artística ao ponto de fazer, a pincel, uma trepadeira em volta da sua porta, onde se viam pássaros [pintados] de várias cores e feitios, muito comprometedores para o crédito profissional do autor (Aluísio de Azevedo, grifos meus).

\section{INTRODUÇÃO}

Este artigo aborda os ofícios de pintor e de designer popular tal como conceituados por Edson Meirelles, fotógrafo carioca, pesquisador, colecionador e criador de um grande acervo de cromos. A frenética atividade de documentação fotográfica e de catalogação do acervo foi executada durante mais de 30 anos (de 1971 a 2004). O material dessa extensa pesquisa está reunido em coleções de diferentes pinturas feitas à mão, tipografias e grafismos, amostras do design popular em diferentes cidades brasileiras. Aliás, essas pinturas muitas vezes sequer são entendidas como obras de arte. Meirelles costuma explicar com um verso a invisibilidade de tais produções. Segundo ele, a pessoa "olha, mas não vê, vê, mas não enxerga" (Edson Meirelles comunicação pessoal, 2012) tais produções ${ }^{1}$. Sua obra, tanto fotográfica quanto textual, desenvolve a problemática da atividade profissional em que o artista, designer ou pintor é entendido muitas vezes como quem atua em um ofício "menor", improvisado, não reconhecido, que transpõe a linguagem oral para o código escrito com "erros" e adaptações. Semelhante à visão do narrador de "O cortiço", que considera o resultado do trabalho do "pintor de tetos e tabuletas" como algo comprometedor para o próprio "crédito profissional" (Azevedo s/d:215) do autor das imagens pintadas. É precisamente pelo olhar de rejeição às letras, às palavras e às formas plásticas pintadas por mãos não treinadas na perspectiva acadêmica, por vezes autodidatas, improvisadas, que Meirelles se dedicou a demonstrar, com suas fotos e seus textos, como essas expressões da criatividade têm valor como repertório plástico popular e coletivo, que pode ser legitimado como arte e/ou como design. O "Projeto Mafuá", como o fotógrafo batizou a sua atividade específica de pesquisa pessoal, teve como tarefa dar visibilidade a essas obras anônimas. O trabalho de Edson Meirelles é um caso exemplar de uma obra coletiva que, em seu conjunto, leva a assinatura daquele que detalhadamente a confeccionou através do meio fotográfico. Ainda que a obra em questão não componha, até agora, o acervo fixo de nenhum museu ou instituição cultural, as fotos desse trabalho, intitulado pelo fotógrafo como "Projeto Mafuá", foram expostas em espaços bastante reconhecidos nos "mundos artísticos" (Becker 1977:9), tais como o Museu de Arte Moderna (MAM), no Rio de Janeiro (1983-1984), as unidades do Serviço Social do Comércio (SESC) São Paulo e Pompeia (2000), em São Paulo, o SESC Araraquara (2001), o SESC Santa Catarina (2004), o Paço Imperial, no Rio de Janeiro (2004), e o Instituto Tomie Ohtake, em São Paulo (2013). O objetivo principal das

1 As entrevistas com Edson Meirelles foram todas realizadas entre os anos de 2011 e 2015, no âmbito da pesquisa realizada para a produção de minha tese de doutorado, no Rio de Janeiro. 
extensas coleções fotográficas, que somam mais de 20 mil cromos, é criar um material de referência sobre a criatividade das produções plásticas populares, objetos gráficos que não costumam ser assinados nem apresentam autoria necessariamente identificada.

O "Projeto Mafuá", de Edson Meirelles, consiste em uma pesquisa fotográfica de documentação de inúmeras pinturas, letras, palavras, números, desenhos, anúncios, tipografias e grafismos não figurativos que estampam diferentes cidades brasileiras, apresentando suportes também distintos, tais como placas, paredes, muros, portas, portais de circo, painéis e brinquedos de parques de diversão, ônibus, carrocinhas de ambulantes, estabelecimentos comerciais, entre muitos outros. Esse conjunto de objetos plásticos traz como tema central a pintura popular - em extensa variedade de formas capturadas pela objetiva de Edson Meirelles. O foco principal do fotógrafo-pesquisador pode ser resumido em uma expressão de Sontag (2004:13): criar "uma antologia de imagens".

Esse projeto é composto por coleções em slides (Omim 2015), textos e publicações sobre a iniciativa, veiculados em revistas especializadas sobre arte e design, bem como por catálogos de exposições realizadas no SESC, no Paço Imperial e no Instituto Tomie Ohtake. Já ao "Acervo Mafuá" se somam os dados produzidos pela minha própria pesquisa, como as entrevistas realizadas com Meirelles entre 2011 e 2015; a digitalização de várias cartelas de cromos e outros documentos; a redação de diários de campo(s) múltiplos, tanto com o autor quanto com o acervo, separadamente.
Nesse sentido, a pesquisa dirigiu-se também para uma "etnografia do arquivo" (Cunha 2004). Olívia Cunha (2004:315) denominou de "tempo imperfeito" uma espécie de "camada" dos territórios arquivísticos: "um conjunto diferenciado de intervenções produzidas ao longo de um tempo imperfeito". De acordo com Cunha (2004:293):

\begin{abstract}
Apesar da familiaridade da antropologia com os arquivos, a relação entre ambos esteve sujeita a diferentes apropriações. A identificação da pesquisa em arquivos com as práticas antropológicas, entre elas a pesquisa de campo e a produção de etnografias, permanece sendo alvo de tensão. Tem sido associada à impossibilidade de estar lá e a formas secundárias de contato entre observadores e 'nativos', mediadas por cima das interpretações intransponíveis e contaminadas. Descrever e interpretar a partir de informações contidas em documentos caracterizaria uma atividade periférica, complementar e distinta da pesquisa de campo e suas modalidades narrativas. Assim, a presença do arquivo na prática antropológica ou está afastada temporalmente daquilo que os antropólogos de fato fazem - caracterizando a prática dos chamados antropólogos de gabinete ou constitui marcadores fronteiriços da antropologia com outras disciplinas - uma vez vinculados à prática dos historiadores, museólogos e arquivistas (Clifford 1994; Stocking Jr. 1986).
\end{abstract}

A autora coloca em foco a importância de observar os arquivos e as coleções não apenas 
como documentos, mas como "resultado de procedimentos sucessivos de constituir e ordenar conhecimentos, realizados não só pelas mãos dos arquivistas, mas por seus virtuais usuários" (Cunha 2004:291). Como uma "usuária" do "Acervo Mafuá", proponho-me ao "processamento antropológico dos conhecimentos”, de que fala Strathern (2013), ao chamar atenção sobre a reflexividade conceitual das "auto-antropologias":

\begin{abstract}
[...] não me refiro à devolução da informação da forma como ela foi oferecida, mas ao processamento antropológico do 'conhecimento', informado por conceitos que também pertencem à sociedade e à cultura estudadas (Strathern 2013:136).
\end{abstract}

São notáveis as afinidades teóricas de Meirelles com os artistas modernistas com verve romântica, folclorista, colecionadora, cuja "atitude documentária" (Clifford 1998:154) revela uma espécie de surrealismo em um "sentido expandido, para circunscrever uma estética que valoriza fragmentos, coleções curiosas, inesperadas, justaposições" (Clifford 1998:133). Além de criar um conjunto extenso de imagens do design e da pintura popular, o "Acervo Mafuá" qualifica e fornece inúmeras formas e reflexões sobre os ofícios específicos de pintor, designer, letristas, pintores de mafuá (parques de diversão), muralistas, autodidatas, pintores ocasionais. $\mathrm{O}$ propósito do fotógrafo é documentar uma obra coletiva de pintores no Brasil de Norte a Sul, a maioria das obras sem assinatura, portanto, anônima (Figura 1).

Procuro, neste artigo, analisar a produção textual que circunda essa extensa "antologia de imagens", bem como certos elementos relacionados ao processo de pesquisa anterior à escrita desses textos, privilegiando a busca de fontes e de referências

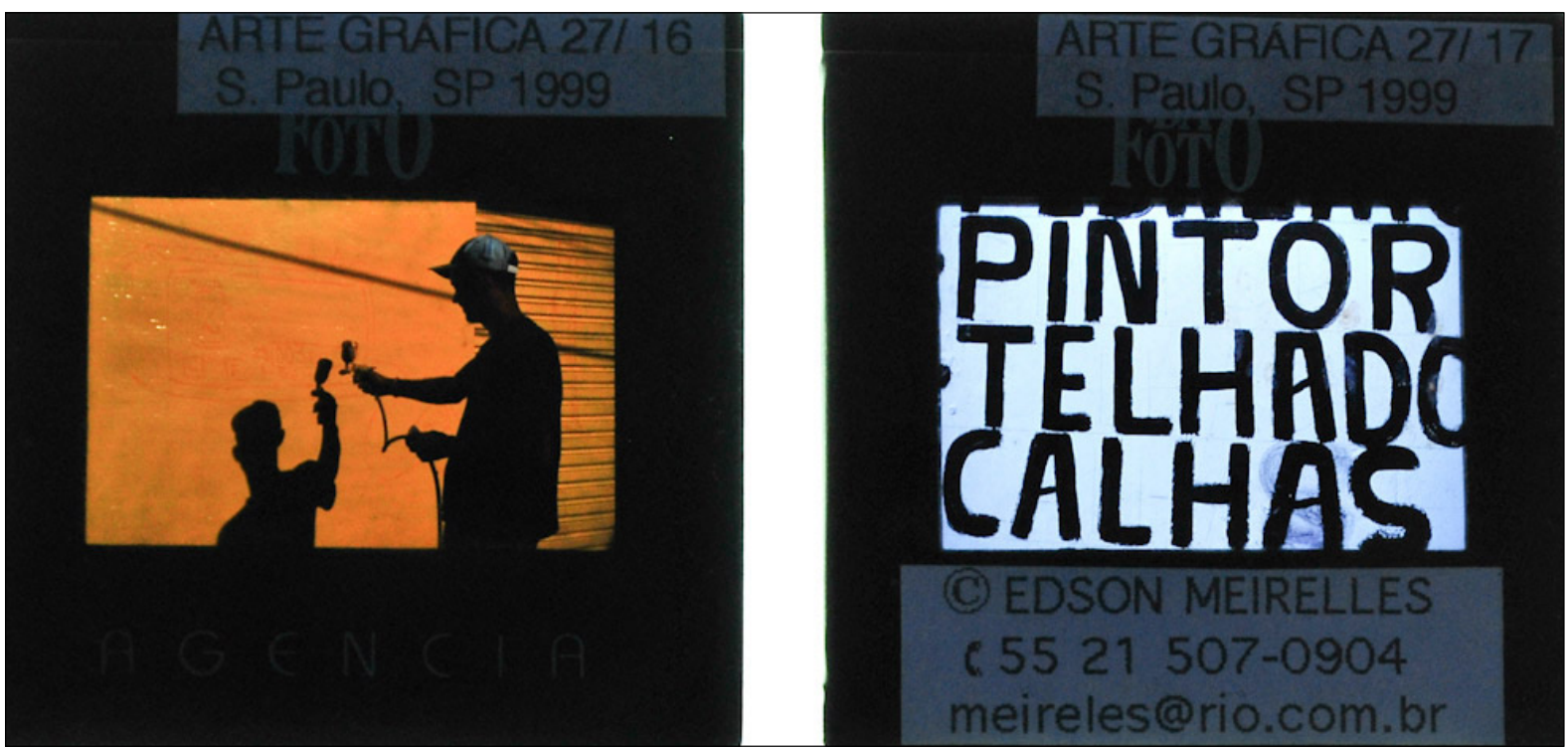

Figura 1 - Os cromos de Edson Meirelles: $1^{\circ}$ cromo - pintor em ação; $2^{\circ}$ cromo - letras de anúncio de pintor. Fotos: Suiá Omim (2011). 
bibliográficas que compuseram, ainda que de modo fragmentado, a arquitetura teórica autodidata do "Projeto Mafuá". Meirelles procura, nestes textos, embasar a sua antropologia feita por imagens. Busco, aqui, debater a hipótese de que o pesquisadorfotógrafo é também um antropólogo, que se coloca em uma posição específica dentro de uma linhagem de produção de antropologias "sem métier" (Geiger 1999), tais como as produzidas por Mário de Andrade (Geiger 1999), Oswald de Andrade (Viveiros de Castro \& Sztutman 2008), Câmara Cascudo (Gonçalves 2007), Lélia Coelho Frota (Velho 2011), entre outros. Meirelles, em sua pesquisa, escolheu alguns desses autores para fundamentar sua antropologia e suas escolhas metodológicas e epistemológicas, mesmo sem os citar explicitamente ${ }^{2}$.

Aqui, a questão dos ofícios é colocada em foco em diferentes instâncias: desde o fotógrafo profissional e pesquisador autodidata, que se pensa como um "antropólogo visual" (sem metiér), até o fato de o próprio objeto de pesquisa de Meirelles ("Projeto Mafuá") problematizar (tanto nas imagens quanto nos textos) o ofício de pintor e de designer popular, na intenção de dar visibilidade às expressões plásticas do "pintor anônimo". Há, ainda, a minha pesquisa, que não deixa de ser uma "metapesquisa", a qual procura entender a questão dos "ofícios raros" (Abreu 2009) neste acervo (de imagens e textos) criado por Meirelles, o qual chamei de "Acervo Mafuá", em referência ao nome de seu "Projeto Mafuá". O conceito de "antropologia reversa", de Roy Wagner (2010), é definidor do caminho de construir uma "meta"pesquisa e de criar os limites de uma "autoantropologia" (Strathern 1987). O desafio é percorrer as imagens e os textos do "Acervo Mafuá" e estabelecer relações entre a(s) criatividade(s) da pintura popular objetivadas pela obra de Edson Meirelles, com aquela empreendida pelo fotógrafo no seu trabalho de colecionar esses milhares e multiformes objetos imagéticos, e relacioná-los por meio da organização e da confecção de um acervo, "inventando", assim, uma cultura (Wagner 2010)

2 Não é incomum encontrar artigos, textos acadêmicos e críticos, livros, teses e dissertações que abordem o "olhar etnográfico" de autores não antropólogos, ou não rigorosamente acadêmicos. Silviano Santiago (1982) considerou Euclides da Cunha, Mário de Andrade e João Guimarães Rosa como autores expoentes de uma "vertente antropológica" da ficção brasileira, principalmente pelo fascínio com a alteridade exercitado nas viagens pelos interiores profundos do Brasil, portando suas cadernetas de notas, observando e escrevendo sobre os outros 'brasis'. Mário de Andrade é um autor bastante estudado como referência nos estudos sobre o patrimônio artístico nacional, não apenas por seus escritos, pesquisas e atuações políticas inovadoras, que delimitam uma "antropologia sem métier" ou "antropologia selvagem" (Geiger 1999), mas também pela contribuição "etnográfica” como fotógrafo "super-turista” (Sontag 1983 apud Carnicel 1998). Essa produção de conhecimentos "não perfeitamente sistemáticos" (Andrade 1991:91) sobre as manifestações populares é entendida como uma característica desta "antropologia selvagem” feita pelos modernistas (Geiger 1999), que influenciou, de algum modo, várias gerações de artistas e pesquisadores. Muitos deles, inclusive, refizeram percursos das viagens de Mário de Andrade, alguns anos depois, documentando e registrando as culturas populares de diversos modos, ou mesmo apostando em uma devoração do popular para entender o brasileiro, o nacional. Ver Omim (2016).

3 “A invenção é sempre uma espécie de 'aprendizado', e o aprendizado é invariavelmente um ato de invenção, ou reinvenção - tanto que é de pouca ajuda falar do aprendizado como um processo ou dividi-lo em 'estágios'. Uma criança participa da dialética da invenção e da convenção tanto quanto um adulto (no máximo, sua memória é um pouco mais curta), e afirmar que ela vive em 'um mundo diferente' não diz muita coisa. Todos vivemos em mundos diferentes" (Wagner 2010:100) 


\section{UMA ETNOGRAFIA TEXTUAL}

Edson Meirelles escreveu uma pequena coletânea de textos visando tanto delimitar seu objeto de pesquisa - "a pintura popular brasileira" quanto elaborar algumas problemáticas relevantes para o "Projeto Mafuá", tais como reflexões sobre a arte, a pintura, a arte gráfica popular brasileira, a arte popular e o design popular no Brasil. Nesses textos, ele enfatiza certas especificidades destes temas em um panorama universal, ao mesmo tempo circunscritos nas discussões sobre uma arte brasileira em um contexto de modernidade.

Os textos, escritos em 2001, estão reunidos sob o título "Pesquisa sobre a pintura popular brasileira". Após estudar os textos minuciosamente, decidi, para fins metodológicos, dividi-los em três partes. Denomino a primeira de "As perguntas e as respostas sobre a pesquisa"; a segunda de "Os escritos sobre arte"; e a terceira de "Dois segmentos específicos do 'Projeto Mafuá'”. Tal distinção analítica e metodológica ajudou-me a perceber a complexidade de questões temáticas dentro do projeto de Meirelles, que parecem ter sido condensadas nas sumárias doze páginas impressas (sem numeração) que a coletânea de textos totaliza.

Os tópicos a seguir partem desta organização da coletânea em duas partes principais, que serão aqui investigadas. O terceiro conjunto de textos aborda dois seguimentos específicos da pesquisa: "Mitopoética do trem fantasma" e "Nilton Bravo, um Michelangelo carioca”, que não serão abordados neste artigo.

\section{AS PERGUNTAS E AS RESPOSTAS DA PESQUISA}

Edson Meirelles inicia os escritos respondendo às três perguntas (elaboradas pelo próprio autor) sobre a sua pesquisa fotográfica. Vejamos a primeira: "O que é a pesquisa sobre a pintura popular brasileira?”. Em seguida, a resposta:

É uma pesquisa que vem sendo executada com recursos próprios ao longo de 29 anos, no exercício de minha atividade profissional de fotógrafo e pesquisador de antropologia visual, em que procuro estudar e registrar, com documentação fotográfica e textos, toda a forma de expressão da "Pintura Popular Brasileira", além de homenagear o pintor anônimo dos subúrbios e das cidades do interior do Brasil, este artista anônimo que consegue transformar letras, desenhos e palavras em exemplos da mais genuína arte popular brasileira (Meirelles 2001:s/p, grifos meus).

Como fica enunciado na resposta apresentada, Meirelles considera suas atividades profissionais como duas, isto é, além de fotógrafo, intitula-se "pesquisador de antropologia visual", especificamente no que se refere à sua produção fotográfica e de pesquisa. O fotógrafo considera-se, assim, pesquisador de antropologia visual, por investir em um projeto de vida (sem qualquer vínculo institucional ou apoio financeiro) dedicado a documentar fotograficamente uma enorme quantidade de pinturas populares.

$\mathrm{Na}$ medida em que o arquivamento de sua pesquisa crescia, ele criava novas classificações e coleções, aproveitando suas viagens de trabalho (fotografando para publicidade, música etc.) ou deslocando-se com seus próprios recursos para capturar, 
com sua câmera, novos exemplares desses traços de tinta advindos da imaginação e das referências "populares". A designação desta segunda atividade profissional, que faz referência direta à área de conhecimento a que esta pesquisa se propõe a contribuir - a antropologia -, merece, assim, um tratamento cuidadoso.

Uma das questões que se colocou como centrais em minha pesquisa (Omim 2016) é, justamente, compreender o que o fotógrafo está chamando de antropologia, mais precisamente de "antropologia visual", já que, rigorosamente, Meirelles não tem formação acadêmica nesta disciplina. Esse ponto compõe uma das principais questões conceituais enunciadas pelo "Projeto Mafuá" e, não por acaso, tornou-se também objeto de investigação desta reflexão sobre ofícios "autodidatas". O autor qualificase como pesquisador de antropologia visual, mas não escreve uma definição sobre a noção de antropologia que está utilizando. Durante uma entrevista, em 2012, tive a oportunidade de perguntar sobre a utilização do termo, ao que me respondeu:

A antropologia visual foi um termo que começou a circular no final dos anos 1970. Até então, a fotografia era um mero instrumento de reprodução. Fotografia não era associada ao contexto antropológico. É a velha guerra contra a fotografia, né? No conceito de suporte da pesquisa antropológica, a fotografia não era importante. O documental passou a ter um peso maior do final dos anos 1980 para cá. Parece pretensioso [qualificar o "Projeto Mafuá" como antropologia visual], mas acho que não... (Edson Meirelles, comunicação pessoal, 2012).
Meirelles aborda, nesta fala, a mudança de status da fotografia no que concerne ao seu reconhecimento como suporte da pesquisa antropológica. O "Projeto Mafuá" apresenta como acervo mais de 20 mil cromos de grafismos populares, em contrapartida com 12 páginas de pequenos textos temáticos. $\mathrm{O}$ fato de o volume de imagens do projeto ser quantitativamente maior do que o textual não se deve apenas a uma assimetria numérica, mas a uma evidente afirmação de que a pesquisa antropológica pode ter a fotografia (e não o texto) como seu principal suporte. Assim, fazer das imagens fotográficas o principal suporte da "antropologia visual" consiste, antes de tudo, em uma escolha epistemológica do "Projeto Mafuá", um modo de conhecer que elege as imagens como principal artefato de descrição e de objetificação de uma cultura.

Sylvia Caiuby Novaes (2005) expõe os vínculos da tradição filosófica racionalista e positivista das Ciências Humanas, ao investigar o uso da imagem, especialmente na disciplina antropológica. O destaque concedido à esfera do inteligível em detrimento à do sensível demonstra as projeções da leitura cartesiana nas quais as imagens são entendidas como engano ou ilusão. A autora explicita que a antropologia acompanhou a virada tecnológica da fotografia e do cinema e, desde o final do século XIX, veio incorporando em pesquisas científicas as câmeras disponíveis (Haddon \& Rivers 1898; Flaherty 1922; Malinowski 1922 apud Caiuby Novaes 2005:109). Na década de 1940, foi publicado o livro "Balinese character: a photographic analysis", de Gegory Bateson e Margaret Mead, considerado a "primeira pesquisa antropológica a se servir sistematicamente da fotografia e do cinema como instrumentos tanto 
na coleta de dados quanto na divulgação de seus resultados" (Freire 2006:64). O livro de Bateson e Mead apresentava fotografias com o acompanhamento de legendas, além de uma introdução de Margaret Mead (Bateson \& Mead 1987). Os autores buscavam entender o comportamento balinês comprometido, de acordo com Bateson, "com métodos fotográficos de registro e descrição" (Bateson 2000[1972]:108, tradução nossa). Nesta questão, Caiuby Novaes (2005:109) argumenta que

\footnotetext{
o valor do documental sobre os recursos imagéticos e não textuais continua sendo pouco explorado e mesmo contestado em vários círculos acadêmicos, a partir da pressuposição de que os textos escritos teriam uma riqueza informativa superior à da imagem.
}

Esta hierarquia do texto em relação à imagem é justamente um objeto de contestação do "Projeto Mafuá", na medida em que as imagens na pesquisa não procuram ser meras ilustrações, mas principalmente um modo de apreensão/descrição/ tradução/objetificação da gráfica popular, que busca investigar e comparar as variedades das habilidades, soluções estéticas e criatividades dos pintores espalhados por um país tão diversificado.

Em outra entrevista realizada em 2014, Meirelles define o "Projeto Mafuá" como: "uma obra de registro documental, uma obra antropológica onde a fotografia é apenas um elemento, um instrumento da minha percepção de uma cultura, de um segmento da cultura brasileira. Este é o foco" (Edson Meirelles, comunicação pessoal, 2014).

Com essa fala, o fotógrafo demonstra que a cultura gráfica em questão se torna visível por meio da documentação iconográfica realizada por ele, sendo as fotografias não só o instrumento, por excelência, de objetificação desta cultura, mas também o principal "controle" da pesquisa de Meirelles (Wagner 2010). Isto é, entendo que a noção de antropologia visual que está em jogo no "Projeto Mafuá" traz como pressuposto a imagem fotográfica como modo de obtenção, que funciona como um "controle" da cultura, na medida em que constato, com Roy Wagner, que: "os objetos de estudo a que nos dedicamos nas artes e nas ciências podem ser vistos como 'controles' na criação da nossa cultura" (Wagner 2010:41).

Retomando esta pergunta-resposta de Meirelles, ainda nos resta analisar sua segunda parte. Tratase também, segundo o autor, de "homenagear o pintor anônimo dos subúrbios e das cidades do interior do Brasil, esse artista anônimo que consegue transformar letras, desenhos e palavras em exemplos da mais genuína arte popular brasileira" (Meirelles 2001:57)

Apresenta-se aqui um personagem-conceitual do "Projeto Mafuá": o pintor anônimo. Nessa homenagem, Meirelles coloca-se a tarefa de dar visibilidade às habilidades (skill) (Ingold 2000) deste ofício, enfrentando a prodigiosa tarefa de documentar o máximo possível de formas, estilos e finalidades dessas obras anônimas. A questão do anonimato demonstra a intenção fundamental da sua obra: mostrar que pinturas feitas à mão e pincel - que alguns consideram "muito comprometedoras para o crédito profissional" do pintor, como o narrador da epígrafe extraída do romance "O cortiço" - são uma espécie de tesouro escondido da arte brasileira. Uma arte invisível, ainda que esteja ao alcance dos nossos olhos a todo momento (Figura 2). Esse 


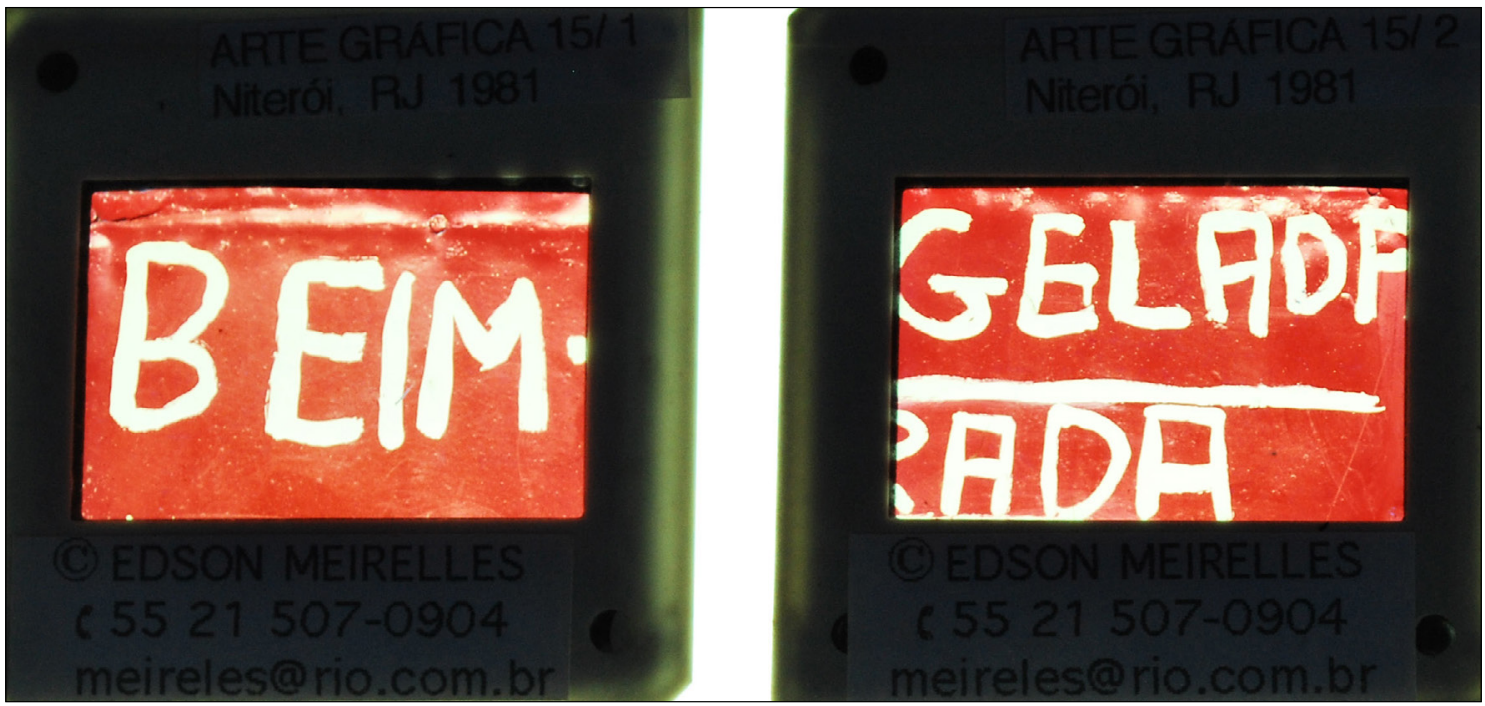

Figura 2 - Os cromos de Edson Meirelles: tipografias do carrinho ambulante da Coca-Cola: design onomatopeico "beim” gelada! Fotos: Suiá Omim (2011).

tesouro só se torna 'real' quando o fotógrafo captura a expressividade disso que não se vê na 'realidade', mas que sua câmera tem a obstinação de registrar. Como aponta Walter Benjamin (1994:104): "cada um de nós pode observar que uma imagem, uma escultura e principalmente um edifício são mais facilmente visíveis na fotografia que na realidade".

De acordo com Omim (2015:54):

O objeto desta pesquisa é um exemplo preciso desta observação de Benjamin sobre a capacidade do enquadramento fotográfico tornar visível elementos do 'real', que fixados, objetificados, dão vida a conjuntos de pinturas, letras, alfabetos, desenhos, carrocinhas de ambulantes, caminhões de ilusionismo, imagens de cenários de trens fantasmas e outros brinquedos de parques de diversão. $\mathrm{O}$ dramaturgo Bertold Brecht já alertava para uma consciência da importância da artificialidade: "menos que nunca a simples reprodução da realidade consegue dizer algo sobre a realidade. [...] É preciso, pois, construir alguma coisa, algo artificial, de fabricado" (Brecht apud Benjamin, 1994:106). Com todas as problemáticas que a palavra 'realidade' implica, Benjamin, tal como Brecht, confrontamse sobretudo com uma reflexão que, no âmbito da antropologia, incidiu em questões sobre as diversas formas de objetificação da cultura (Wagner, 2010; Strathern, 2006; Latour, 1994; Henare et ali, 2007; Miller, 1987; KirshenblattGimblett, 1998; Haraway, 2009; Lagrou, 2009; Gonçalves, 2007), identificando a centralidade da relação sujeito e objeto para o pensamento moderno, e, por sua vez, investindo em novas abordagens etnográficas destas noções, já demasiado "objetificadas", e "sobrecodificadas", 'categorias de ida' apenas, nos termos de Carneiro da Cunha (2010).

As fotografias de Meirelles dão visibilidade a uma série de artefatos culturais produzidos por pintores também invisíveis (Figura 3). O processo 

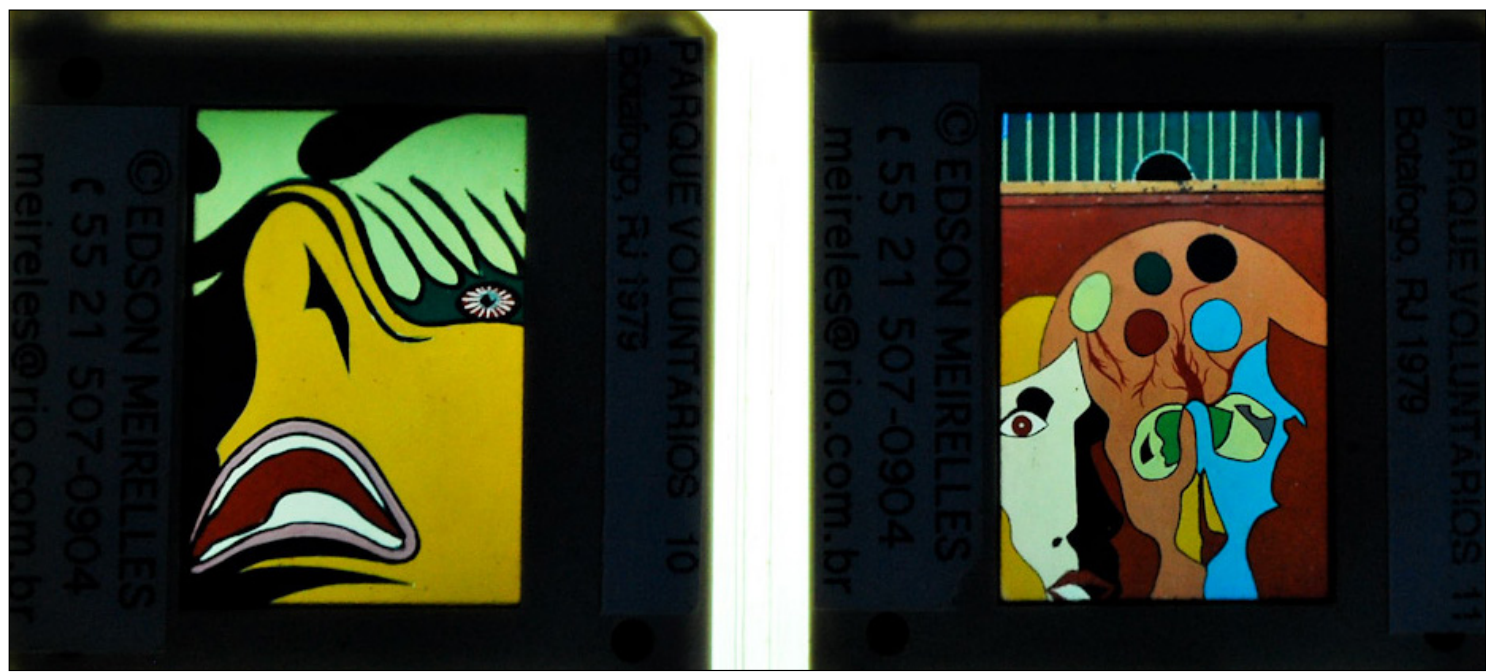

Figura 3 - Os cromos de Edson Meirelles: pinturas na bilheteria de um parque de diversões. Fotos: Suiá Omim (2011).

de documentar obras anônimas foi o que fez nascer o pesquisador que havia no fotógrafo. O que nos leva à segunda pergunta-resposta.

À segunda pergunta - "o que vem realizando a pesquisa sobre a pintura popular brasileira?”-, Meirelles responde:

\begin{abstract}
Vem realizando uma pesquisa objetiva e racional, um levantamento das diversas manifestações da pintura popular brasileira, apoiando em documentação fotográfica e textos de minha autoria executado com planejamento e "rigore ossessivo", como diria Leonardo, cujo resultado são livros que servirão aos apreciadores de arte em geral, e aos estudiosos do fenômeno artístico, uma significativa parcela dos aspectos antropológicos e históricos que a pintura popular encerra (Meirelles 2001:s/p, grifos meus).
\end{abstract}

Nesta segunda resposta, fica evidente a preocupação em qualificar a metodologia utilizada no mapeamento das pinturas populares como "objetiva e racional". Nesse texto, vemos a relevância enunciada pelo fotógrafo em legitimar a seriedade de sua dedicada pesquisa autodidata diante dos rigores acadêmicos, na medida em que utiliza jargões científicos positivistas e racionalistas, já há muito questionados na história teórica da disciplina antropológica. Em seguida, Meirelles utiliza uma adaptação da expressão de Leonardo Da Vinci - o "rigore ostinato" - para qualificar o modo como ele próprio conduziu a documentação das pinturas populares: um rigor obstinado, obsessivo. A expressão de Da Vinci, utilizada por Meirelles, sugere uma analogia entre o rigor empregado nas obras do grandioso pintor e inventor renascentista com aquele utilizado na sua atividade de fotógrafo, cuja obstinação é colecionar fotograficamente as pinturas populares. O rigor da documentação do "Projeto Mafuá", da utilização da técnica fotográfica para o registro dessas pinturas, parece buscar uma sistemática autodidata, cujo propósito seria situar-se "entre" a arte e a ciência, 
tendo apresentado um modus operandi - uma obsessão - de colecionador (Omim 2015, 2016).

Susan Sontag (2004) estabelece uma comparação entre as figuras do fotógrafo e do colecionador, especialmente no que concerne à atribuição de autenticidade aos objetos trazidos à coleção:

\begin{abstract}
Assim como o colecionador, o fotógrafo é animado por uma paixão que, mesmo quando aparenta ser paixão pelo presente, está ligada ao passado. Mas enquanto as artes tradicionais da consciência histórica tentam pôr o passado em ordem, distinguindo o inovador do retrógrado, o central do marginal, o relevante do irrelevante ou meramente interessante, a abordagem do fotógrafo - a exemplo do colecionador - é assistemática. $\mathrm{O}$ entusiasmo do fotógrafo por um tema não tem nenhuma relação essencial com seu conteúdo ou o seu valor, aquilo que torna um tema classificável. É acima de tudo a existência do tema, sua honestidade (a honestidade de um olhar cara a cara, da ordenação de um grupo de objetos), que equivale ao padrão de autenticidade do colecionador; sua equidade - quaisquer virtudes que o tornam único (Sontag 2004:92-93, grifo meu).
\end{abstract}

O caráter assistemático do colecionismo do "Projeto Mafuá" evidencia um rigor constituído pelo tema e por seus vários desdobramentos, em uma atitude semelhante ao que James Clifford (1998) chamou de "surrealismo etnográfico". $\mathrm{O}$ autor propõe um uso expandido do termo surrealismo, que, para além do que se conhece como movimento de vanguarda na França do início do século XX, circunscreve "uma estética que valoriza fragmentos, coleções curiosas, inesperadas justaposições - que funciona para provocar a manifestação de realidades extraordinárias com base no domínio do erótico, do exótico e do inconsciente" (Clifford 1998:133).

A atitude fotográfica de enquadrar pinturas populares por todo Brasil, retirá-las de seus contextos funcionais e montá-las em um acervo de variedades sobre um tema de pesquisa pode, sem esforço, ser comparada às práticas surrealistas de montagem, collage, objets trouvé, o ready-made, e a atitude documentária de culturas. Clifford (1998) explicita a sua utilização do termo etnografia para pensar sobre surrealismo etnográfico, que difere da pesquisa empírica acadêmica. Trata-se de uma
predisposição cultural mais geral, que atravessa toda antropologia moderna e que esta ciência partilha com a arte e a escrita do século XX. O rótulo etnográfico sugere uma característica atitude de observação participante entre os artefatos de uma realidade cultural tornada estranha (Clifford 1998:136).

Clifford demonstra as relações estreitas entre as práticas surrealistas com a emergente noção de relativismo cultural. Como formulou Lagrou (2008:222): "fazer etnografia nos anos 1920 era uma maneira de se concretizar a crítica surrealista da sociedade através da justaposição equivalente de diferentes maneiras de ser. Do surrealismo teria nascido o relativismo cultural". Nessa mesma linha de argumentação, Clifford (1998:137) afirma que o surrealismo é um "cúmplice secreto da etnografia".

Voltando ao texto desta segunda resposta de Meirelles, ele expressa a intenção de transformar 
a pesquisa em livros dirigidos a um público interessado em arte, antropologia ou história. $\mathrm{O}$ autor quer evidenciar a existência de uma metodologia rigorosa de documentação e de pesquisa, cujo desdobramento final seria a produção de livros que possibilitem, assim, sua divulgação como uma fonte inédita de pesquisa, de maneira a ser um produto final de seu trabalho. Meirelles, ao pensar em um artefato que sintetizasse o acervo fotográfico, expressa o insistente "desejo de livro" (Coelho 2010), que seria o objeto final de seu trabalho: transformar seu acervo em um objeto de circulação.

\section{4. "PROJETO MAFUÁ" - ESCRITOS SOBRE ARTE}

O fotógrafo delimitou seis tópicos ao escrever sobre arte, são eles: 1) a arte; 2) a pintura no Brasil; 3) a arte gráfica popular brasileira - um pouco de história; 4) a arte gráfica brasileira; 5) a arte popular; e 6) a arte gráfica popular brasileira. No intuito de criar um recorte específico sobre o ofício do pintor ou do designer popular, selecionei trechos de alguns tópicos dos escritos de Edson Meirelles, para, assim, tecer meus comentários analíticos. Nos Anexos 1 a 3, são destacados trechos selecionados dos textos de Meirelles para análise neste artigo. Todos estes trechos compõem a coletânea de textos "Pesquisa sobre a pintura popular" (Meirelles 2001), que apresenta 12 páginas não numeradas e vários subtítulos, mantidos aqui.

\subsection{A ARTE GRÁFICA BRASILEIRA}

A principal questão colocada no texto presente no Anexo 1 está centrada nos estudos de alfabetos, tipografias e classificação do design, que, de acordo com o autor, deixam escapar as escritas e o design popular das sistematizações e tipologias. No campo do design, costuma-se utilizar um termo específico para definir tais escritas - a tipografia vernacular ou, como o próprio Meirelles designa, a tipografia popular. Neste texto, o discurso se detém em questões bem semelhantes àquelas discutidas no texto "Pintura no Brasil" (Meirelles 2001), contrastando os artistas brasileiros populares do barroco com os estrangeiros da Missão Francesa, que pintavam o Brasil e detinham autoridade institucional na Escola Imperial de Belas Artes. A diferença é que, se, em "Pintura no Brasil”, apareciam apenas os termos "arte" e "arte menor" para descrever as produções populares, no texto do Anexo 1, Meirelles introduz o termo "design" para qualificar obras produzidas por artistas populares. No Anexo 1, os mesmos artistas barrocos considerados por Meirelles como autênticos representantes de uma arte popular são chamados de "designers". O que esta designação pode acrescentar?

Ainda que tais objetos projetem imagens incidentes na "zona de contato" colonial - a exemplo dos santeiros, que produzem objetos da cosmologia cristã, um tema mais do que clássico na arte ocidental, como o dos santos barrocos -, para Edson Meirelles, as características populares são encontradas no estilo. O tema e/ ou o conteúdo das obras não são o referencial principal de qualificação das produções como "brasileiras", mas a forma e o estilo, que, livre das regras e dos modelos metropolitanos, expressem artisticamente o "sentimento de brasilidade". Essa ideia fica clara quando, primeiramente, o autor considera "inautênticas" as pinturas da Missão Francesa que tematizam cenas coloniais do Brasil 
(e, inclusive, evidenciam a assimetria das relações hierárquicas escravocratas) e também quando concebe o período barroco como um marco na produção de uma "estética nacional" e popular, cuja base temática é a religiosidade cristã europeia. Nas palavras de Meirelles (apud Borges 2000:199): "Muitos brasileiros aprenderam as primeiras letras nos livros religiosos. Temos este referencial do inconsciente. O português é muito religioso. A estampa religiosa foi a mãe do desenho brasileiro".

Ao qualificar os artistas barrocos como designers, Meirelles aproxima-se da perspectiva do historiador do design Rafael Cardoso, que reflete sobre "o design brasileiro antes do design", argumento que se fundamenta neste aparente paradoxo. Cardoso (2005:7) afirma:

[...] perdura na consciência nacional o mito que o design teve sua gênese por volta de 1960. [...] Os anos de experimentação entre a abertura do Instituto de Arte Contemporânea do MASP, em 1951, e a inauguração da Escola Superior de Desenho Industrial [ESDI], em 1963, marcam uma mudança fundamental de paradigma. Surgiu nesta época não o design propriamente dito - ou seja, as atividades projetuais relacionadas à produção e ao consumo em escala industrial -, mas antes a consciência do design como conceito, profissão e ideologia.

Nesse sentido, Cardoso (2005:7) defende o uso de um anacronismo "provocativo" para descrever como designer "alguém que provavelmente não reconheceria o sentido da palavra e talvez nem soubesse pronunciála". O livro organizado por Cardoso procura mostrar que antes da importação do modelo concretista/ ulmiano havia uma cultura projetiva "até certo ponto, mais representativa do longo processo histórico de formação da identidade nacional, o qual data do fim do período colonial" (Cardoso 2005:11).

Em uma publicação organizada por Lauro Cavalcanti, resultante da exposição intitulada "Tudo é Brasil", que incluiu fotografias do "Projeto Mafuá”, Rafael Cardoso apresenta outro argumento semelhante ao de Meirelles em relação à questão da nacionalidade brasileira, ao afirmar que a cultura visual erudita no país remete a uma "história de rupturas importadas" (Cardoso 2004:81), citando, por exemplo, os casos da Missão Francesa (1816), da vinda de Le Corbusier (1929), da estada de Max Bill (1951 e 1953) e das movimentações relativas à instauração de uma escola de criação técnica no Museu de Arte Moderna do Rio de Janeiro (1959). Para Cardoso (2004), as perspectivas mais nacionalistas seriam formas de resistência à recorrente imposição de modelos culturais e artísticos estrangeiros, que atropelam outras tradições menos hegemônicas, em nome de uma pretensa racionalidade modernizadora.

A afirmação da identidade nacional seria, para Rafael Cardoso, uma forma de reação/ negação aos modelos exógenos que se desenvolve na "oposição tácita entre ser brasileiro e ser moderno" (Cardoso 2004:81). O autor expressa o incômodo: "o design, moderno de berço e por vocação, lida há pelo menos 40 anos com a provocação irritante de ter que provar que também é brasileiro" (Cardoso 2004:81). Para Meirelles, a presença de elementos da "zona de contato" colonial como o referencial religioso (temática mais do que representada ao longo da história da arte) não constitui um obstáculo para o regime de autenticidade, pois a arte popular 
parece ser reconhecida no seu estilo e não no seu tema. Ao que parece, o traço ou o estilo popular são índices de uma "brasilidade".

A ideia de design, no Brasil, está associada predominantemente ao conceito de objeto industrial, e não ao de objeto manual, artesanal e popular. Adélia Borges, ao abordar a relação entre design e artesanato no Brasil, demonstra que "o ideário racionalista gestado na Europa pós-Revolução Industrial, segundo a qual a máquina liberaria o homem da escravidão do trabalho propiciando felicidade universal, veio para nós [brasileiros] com muita força" (Borges 2011:32). A autora explicita que o processo de industrialização brasileiro teve como base os fundamentos racionais - a ciência, a técnica, a metodologia -, descartando e desvalorizando as produções de artefatos e de cultura material popular, ao contrário dos países em que o design erudito e industrial se desenvolveu a partir da tradição artesanal (por exemplo, Itália, Japão e países escandinavos). No Brasil, essas duas atividades sempre viveram em mundos separados, situados em campos até mesmo opostos. Nas palavras de Borges (2011:31):

\begin{abstract}
A institucionalização do design no Brasil foi feita a partir da ruptura com o saber ancestral manifesto em nossa cultura material. [...] O desejo deliberado de abolir o objeto feito à mão em prol do feito à máquina obedeceu à visão de que a tradição da manualidade era parte do passado de atraso, subdesenvolvimento e pobreza que o futuro promissor proporcionado pelas máquinas nos faria superar.
\end{abstract}

A ideia de design no Brasil, bem como seu processo de institucionalização nos anos 1960, tem a marca funcionalista da escola de Ulm, na Alemanha.
Como aponta Borges, a criação da primeira escola de desenho industrial no Brasil - a ESDI, no Rio de Janeiro -, em 1963, foi "gestada dentro do programa desenvolvimentista do governo Juscelino Kubitschek baseado no investimento pesado na industrialização do país, vista como a única forma de crescer 'cinquenta anos em cinco"' (Borges 2011:32).

De acordo com Rafael Cardoso, a influência universalista daEscola de Arte Bauhaus, da Alemanha, em que a "forma segue a função", consolidou, no Brasil, uma atitude de

\section{antagonismo dos designers com relação à arte e ao artesanato. [...] Acabaram prevalecendo aquelas opiniões que buscavam legitimar o design ao afastá-lo da criatividade individual e aproximá-lo de uma pretensa objetividade técnica e científica (Cardoso 2000 apud Borges 2011:33).}

A visão ulmiana apresentava um modelo internacional que enxergava as culturas populares, indígenas, negras etc. como indícios do atraso e do subdesenvolvimento do país, aspectos que deveriam ser superados por meio de uma acelerada produção industrial.

No Brasil, no entanto, e pelo menos desde os anos 1960, destacam-se importantes produções no sentido de haver uma aproximação do design com os conhecimentos populares, tais como a de Lina Bo Bardi e de Aloísio Magalhães, que defenderam perspectivas contrárias à "importação acrítica dos padrões de pensamento e prática da Escola de Ulm" (Borges 2011:32). Borges demonstra que tanto Lina Bo Bardi quanto Aloísio de Magalhães estariam voltados para a produção artesanal e para a cultura popular como a base de fundamentação de um design 
propriamente brasileiro ${ }^{4}$. A partir da segunda metade da década de 1970, o problema da identidade nacional ocupou um dos primeiros planos nas preocupações dos designers. Esse tipo de pensamento, do qual Aloísio foi o expoente, implicava a análise do que fosse nacional e também do que fosse popular (Souza 1996:277).

Interessante notar que a década de 1970 é justamente o período inicial da pesquisa de Meirelles. Em 1972, trabalhando com criação de stands em feiras industriais, em várias cidades do Nordeste, o fotógrafo percebeu a atividade profissional de letrista, as habilidades manuais destes pintores (sejam os profissionalizados por cursos técnicos ou aqueles autodidatas) como um campo de pesquisa e de documentação das expressões plásticas indicativas das práticas criativas brasileiras de base, que estariam ameaçadas pelo avanço da industrialização.

Essa preocupação de Meirelles com uma investigação das gráficas populares pode ser pensada como uma visão próxima daquela que João Souza Leite chama de "outra vertente do design brasileiro" (Souza Leite 2006). Essa outra vertente do design no Brasil é considerada por Borges (2011) como sendo as "vozes isoladas" do design brasileiro. Segundo Souza Leite (2006:252), "Marcadamente sob a influência europeia, a arte concretista no Brasil - de origem paulista - se contrapôs ao modernismo brasileiro dos anos 20-30, e foi vitoriosa na institucionalização de um novo modelo pedagógico para o design".

Avançando em seus argumentos, Borges (2011:260) afirma:

Lina Bo Bardi tentou delinear outra
vertente - à qual se pode dizer que Aluísio
Magalhães pertencia - ao formular em
Salvador, Bahia, um projeto de escola de
desenho industrial atrelado à produção
artesanal nordestina. De certo modo, Lina
recuperava uma linha de ação vinculada
ao ensinamento dos ofícios, inserida numa
visão cultural mais ampla, não codificada
pelo vocabulário do construtivismo
internacional, aqui concretismo. Em 1962
- portanto, contemporâneo às discussões
para implantação da ESDI, Lina projetou
uma ampla e detalhada ação para a criação
de uma "Escola de Desenho Industrial e
Artesanato", visando estabelecer outros
rumos para o desenvolvimento do design
no país.

Pedro Luiz Souza explicita que a reação crítica ao formalismo técnico do modelo da Bauhaus foi essa "tendência nacionalista do design" ou "a ideia de um design sintonizado com uma realidade nacional" (Souza 1996:232) ou, ainda, um “design de identidade nacional" (Souza 1996:303), que, ao invés de reproduzir

4 Sobre a relação entre design e identidade nacional, Anastassakis (2011:57-58) comenta que diversos autores abordaram esta problemática, levantada tanto por Lina Bo Bardi quanto por Aloísio Magalhães: "Se vários deles trazem para a discussão apenas um ou outro (por vezes os aproximando ou contrastando com outros atores) (Cardoso, 2004, Cornejo, 2008, Souza, 1996), alguns abordam de forma explícita as relações (implícitas) entre os posicionamentos de ambos (Borges, 2009, Cara, [(2008) 2010], Chagas, 2002, Souza Leite, 2006, Lessa, 1994, Moraes, 2006, Nobre, 2008). Acompanhando alguns de seus trabalhos é possível perceber, então, em que quadro maior de discussão esses autores têm comentado as atuações de Lina Bo Bardi e Aloísio Magalhães, trazendo à tona, assim, as suas leituras sobre as contribuições de Lina Bo Bardi e Aloísio Magalhães para a conformação de um design vinculado de forma mais a uma identidade cultural brasileira. Ao atribuírem a Lina Bo Bardi e a Aloísio Magalhães um certo pioneirismo na crítica à influência germânica entre o design brasileiro, esses críticos delegam ao pernambucano e à italiana poderes de criação de uma vertente (ou seja, de formação de uma discursividade (Faria, 2002), que só é assim nomeada por eles, a posteriori, mas que tem sua gênese localizada, por eles, nas proposições e atuações dos dois, em suas trajetórias profissionais”. 
o design endurecido pela noção industrial funcionalista e universalista, teria caminhado em uma direção "mais antropológica" e culturalista, inclusive mais próxima dos modernistas dos anos 20 e 30, especialmente de Mário de Andrade (Lessa 1994).

Voltando, assim, ao texto de Meirelles presente no Anexo 1, quando ele afirma que os artistas barrocos, pintores e artesãos populares são designers, renovadores "dos velhos valores metropolitanos", está fomentando um conceito de design "contracultural", isto é, contra o convencional industrial, universal técnico e racional e apoiado pelo Estado. Edson Meirelles procura, com o design popular, estender o conceito de design erudito/ acadêmico, acenando como expressão de autenticidade de uma arte "tipicamente brasileira”. Como diz a epígrafe deste artigo, de autoria dePicasso, "A arte não é a aplicação de uma regra de beleza, mas aquilo que o instinto e o cérebro podem conceber além de qualquer regra”. Estes aspectos contracultural, minoritário, antropológico do designe da arte fundamentam as bases de uma "política da visualidade" (Demarchi 2014) que a obra de Meirelles procura "inventar", através do enquadramento desses objetos gráficos de toda sorte, embasando o inventário de um patrimônio cultural gráfico.

A disposição contraculturalista foi acabar desembocando no processo de desrecalque das múltiplas personalidades que nos compõem e no reconhecimento pleno da pluralidade cultural brasileira. É assim que podemos falar da contribuição da contracultura para o alargamento e o aprofundamento da consciência e da sensibilidade antropológicas no Brasil, produzindo rachaduras irreparáveis no superego europeu de nossa cultura (Risério 1995:30).

O uso dos conceitos design e arte tem a intenção de afirmar não apenas uma diferença, mas uma aproximação e um "alargamento" do conceito de arte, que passaria a abarcar objetos gráficos mais "úteis", "cotidianos", "tipográficos", como as escritas populares (Figura 4). A distinção entre os termos simplesmente não importa: “Arte gráfica ou

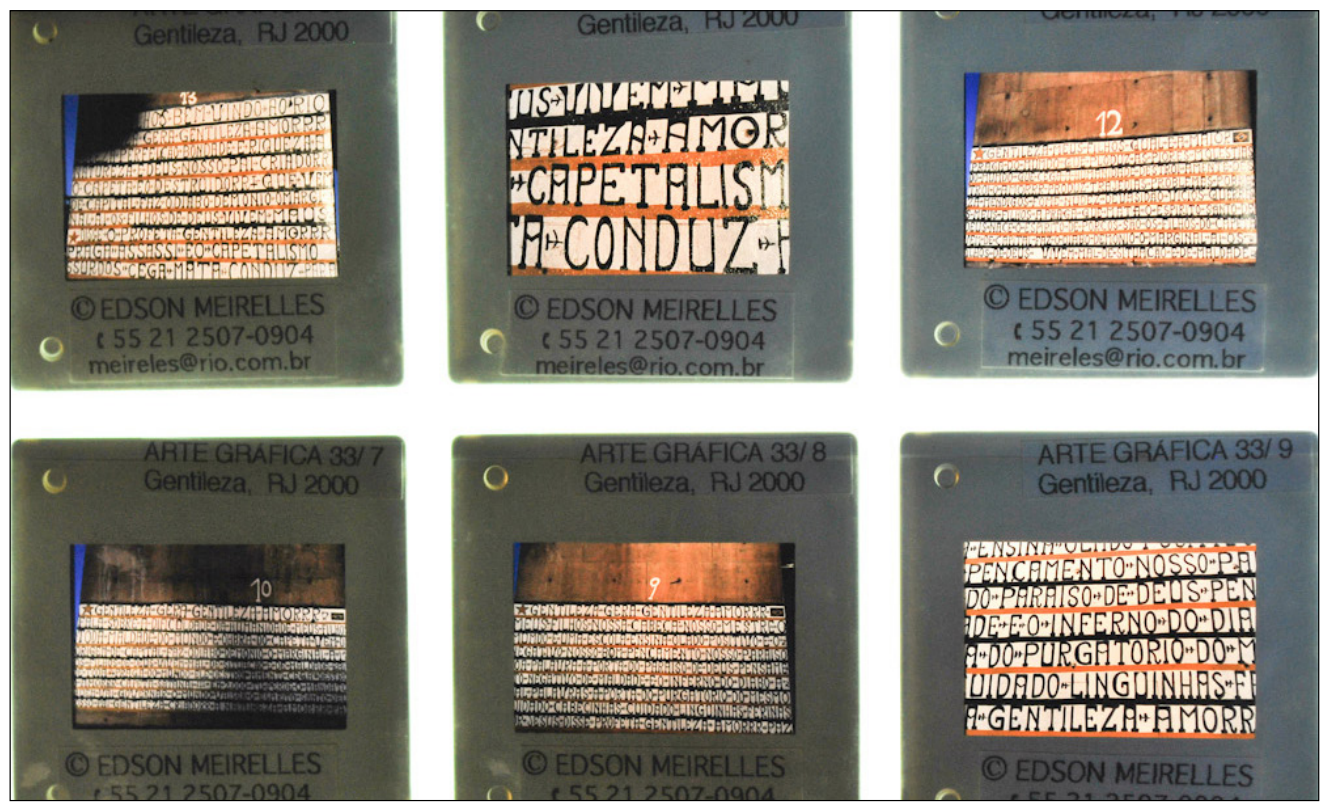

Figura 4 - Os cromos de Edson Meirelles: viaduto pintado pelo Profeta Gentileza, Rio de Janeiro, em 2000. Fotos: Suiá Omim (2011). 
design popular é tudo a mesma coisa: o modo do povo se expressar através da pintura" (Edson Meirelles, comunicação pessoal, 2012). Uma afirmação de Lagrou (2009:14) sobre as relações entre as noções de arte étnica e arte contemporânea nos permite sintetizar o pensamento de Meirelles e o alargamento dos conceitos de arte e de design que ele quer proporcionar: "somente quando o design vier a suplantar as 'artes puras' ou 'belas artes' teremos nas metrópoles um quadro similar ao das sociedades indígenas".

\subsection{A ARTE POPULAR}

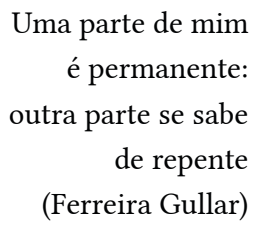

Ferreira Gullar, poeta e crítico de arte, um dos nomes do movimento neoconcreto, no poema "Traduzir-se", evidenciou algumas inquietações ontológicas do eu-lírico, que se encontra dividido em sentimentos, pensamentos e ações aparentemente opostas: "Uma parte de mim / é todo mundo / outra parte é ninguém: / fundo sem fundo". O eulírico experimenta uma contradição pela presença simultânea de sentimentos de pertencimento e de adequação à vida cotidiana: "uma parte de mim / almoça e janta"; e sentimentos de estranheza, delírio e solidão: "outra parte / se espanta". Na tentativa de expressar a existência e convivência ambígua dessas duas partes, ou seja, de "traduzir uma parte / na outra parte", que se torna "uma questão de vida ou morte", o autor elabora a seguinte questão: "será arte?". Esta ideia que separa o tipo de atitude do homem comum, cotidiano, que simplesmente segue a vida em suas necessidades primordiais, da atitude daquele que questiona, se espanta e necessita da expressão da sua singularidade consiste em uma imagem mais alinhada ao senso comum do pensamento ocidental para delimitar a distinção entre o homem comum e o artista, que supõe uma oposição entre arte e vida. A pergunta que guia o poema - "será arte?" - parece trazer à cena um elemento de afirmação dos textos de Meirelles: evidenciar que a gráfica cotidiana, o design, o popular, o coletivo, o anônimo, as escritas menores, o comum, o espontâneo podem, sim, ser arte.

No texto de Meirelles constante do Anexo 2, ele reflete, primeiramente, sobre a arte sob um ponto de vista mais geral, apresentando a inteligência, a sensibilidade e a habilidade como elementos da criação artística, sendo esta considerada como uma ação individual que está em profunda relação com a cultura e a comunidade em que o indivíduo se vê inserido. Meirelles reflete sobre certas questões artísticas por meio de reflexões sociológicas, como as noções de indivíduo, de coletividade, de povo e de identidade cultural (urbana ou rural), sem, no entanto, abordar a questão da "brasilidade". A arte popular é apresentada como "uma arte de todos", sendo entendida sob o signo da apropriação, da assimilação e da mimesis.

Essa questão do individual e do coletivo é um aspecto analítico bastante evocado nos estudos das artes populares. Ao refletir sobre o acervo do Museu Casa do Pontal, a antropóloga Angela Mascelani (2011:s/p) aponta:

em alguns casos, o destaque é o artista individual, com o seu pensamento, sua criação formal e soluções plásticas encontradas. [...] Em outros, a ênfase 
está posta na coletividade, com suas marcas comuns, seja no uso das cores, seja nas formas ou nos temas preferenciais.

E menciona, assim, as produções de barro em Caruaru, em Pernambuco; no Vale do Jequitinhonha, em Minas Gerais; objetos de certas áreas do Cariri, no Ceará, e no Vale do Paraíba, em São Paulo.

Meirelles parece conceber, entre outras artes, que a "arte popular" é aquela que apresenta mais influência do meio social, sendo uma "manifestação do coletivo". Como observa Mascelani (2011:s/p):

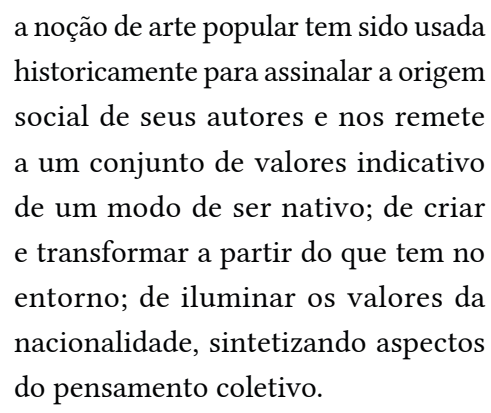

Quando Meirelles afirma que as mãos são do artista popular, "mas a criação é da coletividade", ele explicita a existência de um repertório coletivo de formas, figuras, temas, tipos, cores, que seriam, assim, apropriados pelas habilidades manuais do artista. Esse domínio público "do popular" seria uma espécie de patrimônio coletivo, uma coleção de objetos que são versões de uma forma adotada coletivamente, mas passíveis de serem apropriados, remontados, personificados, estilizados pelas mãos dos artistas. Meirelles discute um caráter mais coletivo da criatividade do povo como um modo de distinção do modelo predominantemente "autoral" da arte ocidental, onde o artista é entendido como um indivíduo iluminado que cria.
A inexistência da figura do artista enquanto indivíduo criador - cujo compromisso com a invenção do novo é maior que sua vontade de dar continuidade a uma tradição ou estilo artístico considerado ancestral - é outra diferença crucial. Não que artistas contemporâneos metropolitanos não trabalhem dentro de tradições estilísticas bem definidas. Vale lembrar que o fundador da arte conceitual, Marcel Duchamp, instalou seu urinol há praticamente um século, em 1917, e desde então o paradigma do fazer artístico não mudou, mas ideologicamente a figura do artista se projeta como inventor do seu próprio estilo, como inovador incessante, ao modo de um Picasso - emblema do Modernismo na arte. A fonte de inspiração e legitimação se encontra no gênio do artista que é visto como agente principal no processo de relações e interações que envolvem a produção de sua obra, uma obra produzida com o único fim de ser uma obra de arte (Lagrou 2009:14).

Nos redutos artísticos populares citados por Mascelani (2011), encontram-se inúmeros objetos com temáticas, escolhas formais, uso de cores que se assemelham, mas que são feitos por artistas diferentes, por exemplo as esculturas de barro das famílias de retirantes, os personagens do bumba meu boi, do maracatu, as diversas profissões que se encontram na Feira de Caruaru, 
as noivas e moringas feitas pelas artistas do Vale do Jequitinhonha ou os santeiros no Sertão do Cariri. Na poesia popular dos folhetos, também se coloca a questão da coletividade/criatividade para a qual Gonçalves (s/d) encontra uma saída benjaminiana:

O poeta de Cordel, como o entende Ruth Terra (1983: cap. 2), deve ser compreendido para além de uma figura personalizada de autor, pois compartilha uma visão de mundo com seu público. Se esta ideia parece ser absolutamente verdadeira, deve-se também evitar tomar o contexto em sua radicalidade de modo que elida a criatividade individual e poética reduzindo a criação a uma comunidade narrativa, a uma sociedade. Uma saída possível para o impasse contexto/ criatividade é a encontrada na definição de Benjamim (1980:63), em que a narrativa seria ao mesmo tempo uma fórmula social e pessoal de criação, como a obra de um artesão: adere à narrativa a marca de quem a narra como na tigela de barro a marca das mãos do oleiro (Gonçalves s/d:34).

Outra questão colocada por Meirelles é a dicotomia entre o popular urbano e o rural. $\mathrm{O}$ urbano é considerado por Meirelles como mais suscetível à "domesticação" tecnológica do mundo moderno, "por maior que sejam os seus apelos e seduções, continua popular”. Ele é confrontado com o popular rural, que sente mais lentamente o impacto da urbanização e das novas tecnologias. Os meios tecnológicos são vistos como sedutores e apelativos, a cultura de massa é entendida como máquina de captura do irrefreável processo civilizatório. Meirelles, ao fim, expressa uma leitura mais "evolucionista" da criatividade, quando afirma, conforme o trecho que compõe o Anexo 2, que "o homem do povo vai dando vazão à sua sensibilidade, e expressando a sua beleza com sua arte espontânea e simbólica, provando que não importa o estágio evolutivo de sua cultura, ele é um animal que cria” ${ }^{5}$.

Essa concepção de arte popular expressa por Meirelles pode ser pensada tanto em relação às teorias mais materialistas da arte ocidental (conceitual, surrealista, modernista) quanto em face daquelas teorias mais perspectivistas da "arte das sociedades contra o estado" (Lagrou 2011; Clastres 1978). De acordo com Lagrou (2009:11), “[...] não é porque inexiste o conceito de estética e os valores, que o campo das artes agrega na tradição ocidental, que outros povos não teriam formulado seus próprios termos e critérios para distinguir e produzir beleza”. Entre os indígenas Kayapó, aponta a autora, todos os membros do grupo têm o direito de produzir enfeites e artefatos cerimoniais, mas o direito de "uso" dos bens é definido pelo nome do indivíduo.

O fator considerado responsável pelo êxito de um artefato depende do tipo de arte em questão: pintura corporal, tecelagem, trançado, cerâmica, escultura, produção de máscaras ou arte plumária. Quando predomina a dificuldade técnica, serão prezadas a concentração, a habilidade, a perfeição formal e a disciplina do mestre. Mas quando predomina a expressividade da forma, a fonte de inspiração é quase sempre atribuída a seres não humanos ou divindades que aparecem em sonhos e/ou visões.

5 Sobre este assunto, ver Strathern (2013). 
Dificilmente se responsabilizará a 'criatividade’ do artista pela produção de novas formas de expressão. Ele está mais para aquele que capta e transmite ao modo de um rádio transistor do que para um criador. Preza-se mais sua capacidade de diálogo, de percepção e de interação com seres não humanos, cuja presença se faz sentir na maior parte das obras de aspecto figurativo, do que a capacidade de criação ex nihilo, criação do nada. Essa ideia de ser mais receptor, tradutor e transmissor do que criador vale para a música, a performance e a fabricação de imagens visuais e palpáveis (Lagrou 2009:22).

Como demonstra Lagrou, o artista kayapó é antes "um rádio transistor do que um criador" que interage, recebendo e transmitindo, afetado pelos seres não humanos. Acredito que esta imagem do artista como "rádio", capaz de captar e de disseminar conhecimento e estética coletivos, traz rendimentos no que tange à argumentação deEdson Meirelles sobre a arte popular como um repertório de possibilidades apropriativas e criativas de produção de "diferenças" e de estilos, a partir de instâncias e domínios coletivos com as articulações particulares de cada artista.

Não pretendo, com essas aproximações, criar "identidades" nem "continuidades" entre as tão diferentes concepções de arte (vanguarda, ameríndia, popular). Entendo apenas que há uma "zona de contato" entre os modos de pensar as criatividades nos mundos artísticos metropolitanos, urbanos e nas cosmologias artísticas contrainstitucionalizantes. Essa questão será melhor elaborada no próximo e último texto de Edson Meirelles, disponibilizado no Anexo 3.

\subsection{A ARTE GRÁFICA POPULAR BRASILEIRA}

Neste último texto de "Escrito sobre arte", em Meirelles (2001), presente no Anexo 3, o autor delimita o conceito de "arte gráfica popular brasileira", que consiste em uma espécie de termo geral, definidor do objeto da sua pesquisa. Além de nomear uma das coleções do "Projeto Mafuá", o termo “arte gráfica popular brasileira" foi criado para conceituar a totalidade das variedades "ontológicas" da pintura popular brasileira, tanto aquela rigorosamente colecionada por Edson Meirelles quanto as tantas outras que se espalham pelo Brasil ${ }^{6}$. O conceito se aplica ao conjunto de expressões gráficas e delimita também uma técnica específica: a pintura feita à mão com pincel, sem mediações de outros instrumentos como aeróglifo, serigrafia ou spray. De acordo com Meirelles:

6 Carlo Ginzburg (1989:178-179) aborda “o rigor flexível” do "paradigma indiciário" nas Ciências Humanas como uma inspiração do método de Morelli, pseudônimo do médico italiano que inspirou Freud na criação da psicanálise: "Mas pode um paradigma indiciário ser rigoroso? A orientação quantitativa e antiantropocêntrica das ciências da natureza a partir de Galileu colocou as ciências humanas num desagradável dilema: ou assumir o estatuto científico frágil para chegar a resultados relevantes, ou assumir um estatuto científico forte para chegar a resultados de pouca relevância. [...] Mas vem a dúvida de que este tipo de rigor é não só inatingível mas também indesejável para as formas de saber mais ligadas à experiência cotidiana - ou, mais precisamente, a todas as situações em que a unicidade e o caráter insubstituível dos dados são, aos olhos das pessoas envolvidas, decisivos. [... ] O rigor flexível (se nos for permitido o oxímoro) do paradigma indiciário mostra-se ineliminável. Trata-se de formas de saber tendencialmente mudas - no sentido de que, como já dissemos, suas regras não se prestam a ser formalizadas nem ditas. Ninguém aprende o ofício de conhecedor ou de diagnosticador limitando-se a pôr em prática regras pré-existentes. Neste tipo de conhecimento entram em jogo [...] elementos imponderáveis: faro, golpe de vista, intuição”. 
deu muita força, fizeram materiais maravilhosos. E pediram para eu mudar o termo "arte gráfica popular brasileira", pois gráfico dentro do contexto literário vernacular, seria a arte da impressora, das pessoas que trabalham dentro da gráfica. Mas o meu conceito é muito mais elástico. Eu comecei a chamar de designer popular, que é um pouco pretensioso porque não há termo em português para isto. Eu gosto mais de arte gráfica popular brasileira. Eu comecei a pensar em mudar o termo por causa da solicitação do pessoal da ABIGRAF. Mas não importa, arte gráfica ou design popular é tudo a mesma coisa: o modo do povo se expressar através da pintura (Edson Meirelles, comunicação pessoal, 2012, grifos meus).

A técnica privilegiada pela câmera-olho de Meirelles foi nomeada pelos especialistas como "design popular", embora o fotógrafo demonstre não se importar com o termo "correto", contanto que se reconheça a singularidade da arte em questão. Para Antônio Risério (1995:73), “o design é a necessidade do mundo de se sentir global. Inteiro. Humanos vivendo em um sistema internacional". Meirelles parece justamente "estranhar" como um conceito de sofisticação "global" como o design pode ser utilizado para abarcar uma arte tão "popular" e "brasileira”. É como se expressasse a necessidade de um "conceito nativo", em detrimento de um "conceito exportado".

Por excelência, o conceito nativo do presente estudo é o de arte gráfica popular brasileira que delimita, como vimos, um conjunto específico de expressões pictóricas. No entanto, é importante ressaltar que Meirelles utiliza o conceito de design, embora o considere "mais elástico", abarcando a integridade das variedades de objetos pictóricos, que são classificados pelo conceito de arte gráfica popular brasileira. A atividade sobre a qual a obra do fotógrafo se debruça é diferenciada narrativamente de categorias e de terminologias "estabelecidas" por diversos mundos artísticos, tais como artesanato, arte popular e folclore. $\mathrm{O}$ "Projeto Mafuá” tem como justificativa criar um registro documental que conceda visibilidade à pintura popular, justo aquela que, entre as artes "rejeitadas e populares", apresenta a peculiaridade de ser o "nó górdio", isto é, a mais desconhecida e ignorada de todas. Meirelles diferencia, por exemplo, a sua conceituação de arte gráfica de outras produções populares, como artesanato e arte popular:

Estes temas já foram explorados:
folclore, artesanato, arte popular. A
pintura popular é que é o nó górdio. O
sentido de rejeição de toda arte popular
por conta da cultura dominante, a
cultura erudita sempre rejeitou o
popular. Veja a dificuldade de o samba
ser aceito. As artes populares sempre
tiveram uma dificuldade de aparecer,
de ter um registro sério (Edson
Meirelles, comunicação pessoal, 2012).

O texto do Anexo 3 é iniciado com a demonstração dos diversos suportes em que se produz a arte gráfica popular brasileira, qualificada como "esta estética tão nossa quanto ignorada". Ao analisar os suportes enumerados pelo autor - rótulos de bebidas, garrafadas e unguentos, portas de circos e shows de ilusionismo, reclames comerciais, barracas, placas, cartazes e carrocinhas de ambulantes -, fica evidente que o termo arte 
gráfica é uma delimitação geral do seu objeto de pesquisa, que engloba todos os seguimentos e coleções do "Projeto Mafuá". Minha hipótese é a de que o conceito de arte gráfica engloba os conceitos de design e da tipografia popular, e não o contrário. Isso ocorre na medida em que o ponto crucial para o autor é a operação conceitual de converter anônimos em artistas, reivindicando um reconhecimento às produções pictóricas "cotidianas", "utilitárias", "imperfeitas", "populares”, que estão em relação de alteridade com as produções legitimadas pelos mundos artísticos e museológicos.

O autor prossegue a argumentação, afirmando que a "beleza" encontrada nessas plasticidades populares se expressa de "maneira distinta, combinando ou isolando entre si o ritmo de cores, das formas e do movimento", conforme o Anexo 3. Afirma, deste modo, que há uma beleza "outra" nestas produções, modificando os termos de valoração estética estabelecida pela cultura dominante.

O artista gráfico popular é invariavelmente dotado de uma intuitiva sabedoria plástica, que se manifesta em contraposição à sua ausência de técnica e, ao mesmo tempo, dá suporte tão característico aos autodidatas, nos quais se destaca o elementarismo das cores quase sempre puras, os sensos decorativos, a expressiva simplicidade do desenho e a originalidade do traço (Meirelles 2001:s/p)

Meirelles afirma o valor desta arte, inclusive pela característica que distingue como "ausência de técnica”, apreendida no sentido de serem produções que não dialogam com os rigorosos padrões acadêmicos de perspectiva, composição, luz, cores, matizes. A "ausência de técnica" dos artistas gráficos é entendida como uma "intuitiva sabedoria plástica", que denota um elemento do autodidatismo e da capacidade de improviso desses artistas. O autor chega à seguinte formulação, conforme o Anexo 3: "a ausência de técnica acaba transformando-se na maior qualidade de sua obra, [...] não sendo exagero afirmar que, quanto menos perfeita sua técnica, mais pleno seu sentido artístico". Nesse aspecto, Meirelles cria, nos termos de Clastres, uma "rotação da perspectiva", uma "revolução copernicana", que converte uma suposta "ausência" em qualidade. Assim, a alteridade e a não adequação aos regimes artísticos eurocêntricos tornam-se o ponto de partida da "originalidade" de tais expressões.

Lévi-Strauss e Clastres foram contemporâneos e têm em comum a procura das implicações filosóficas de escolhas, respectivamente políticas e artísticas, feitas pelos povos de forma coletiva. Vemos, deste modo, surgir em Lévi-Strauss o que poderíamos chamar de uma "arte dos povos contra o Estado". Ambos os autores usam a oposição nós/outros como meio heurístico para se pensar a possibilidade de outras filosofias políticas, também para o futuro e o presente do Ocidente. Esta possibi- lidade será por sua vez explorada por Deleuze e Guatarri (1976 [1972]). Clastres afirma querer fazer para o conceito de política e de poder o que Lévi-Strauss fez para o de razão, invertendo a lógica do olhar para perceber no lugar da falta a abundância 
de um discurso outro sobre o modo de se estar no mundo (Stolze Lima \& Goldman, 2003). Em O Pensamento Selvagem (1976), Lévi-Strauss propõe esta inversão de perspectiva para a compreensão da razão humana através de um olhar sobre a arte, a arte representando aqui um modo de conhecimento sobre o mundo (Lagrou 2011:750-751).

É justamente a arte como um modo de conhecimento "popular" sobre o mundo o foco do conceito de arte gráfica popular brasileira de Edson Meirelles, tendo como ponto de partida um valor artístico que toma "no lugar da falta a abundância” (Lagrou 2011:751). Por exemplo, o artista gráfico popular, tal como observado por Meirelles, é aquele "cara que leva jeito" para pintar. O pintor ou letrista faz um uso oral da língua, que, por sua vez, é expressa por meio da palavra escrita. Meirelles ressalta que a existência de um "erro" ortográfico ou gramatical na palavra pintada não compromete a comunicação do que está sendo dito. Desse modo, para o fotógrafo, essa apropriação "selvagem" da língua escrita torna-se apenas um aspecto singular, de base, do design popular.

Meirelles define o "popular" na sua conceituação de arte gráfica em contraposição às artes acadêmicas:

O designer popular desconhece a técnica acadêmica escolarizada, a artificialidade, e apresenta-se quase sempre de forma não codificável por elementos alheios à sua realidade socioeconômica-cultural, sendo por isso interpretado como rudimentar e imperfeito, enfim, uma expressão artística de má qualidade e desprovida de valor documental. Sem dúvida, essa interpretação se deve ao fato de a palavra "popular", de conotação pejorativa, estar associada à produção vulgar, pobre e sem valor (Meirelles 2003:34).

O autor ressalta a diferença da condição do designer popular em relação ao designer/artista reconhecido socialmente como tal, ou seja, identifica uma assimetria entre a arte popular e a arte consagrada. É possível ver, neste posicionamento, uma atitude semelhante àquela apresentada por Lévi-Strauss, no livro "O pensamento selvagem" (2008), quando afirma que uma das vocações destas outras formas de pensamento, ação e produção é justamente provocar "o alargamento da visão ocidental". Podemos extrair desta comparação a ideia de que um dos objetivos de Meirelles é justamente desestabilizar o conceito de arte, horizontalizando, ou melhor, transversalizando (Clastres 1978) certas oposições duais: o popular e o erudito, o formal e o informal, o primitivo e o civilizado, o belo e o feio. Na base destas oposições, residem as categorias de alteridade "ocidentais" em relação às quais Meirelles parece estar agindo "contra".

Sem dúvida, Meirelles teve contato com o pensamento de Lévi-Strauss através do livro de Lélia Coelho Frota (1978), "Mitopoética de 9 artistas brasileiros". No livro, a autora se propõe a analisar "a produção e comportamento social dos artistas comumente chamados de primitivos", e ressalta que as "especulações relativas à criatividade de conotação popular, ou a ela recorrentes, tornam, como é notório, especialmente difícil e delicada uma primeira conceituação dessas manifestações artísticas" (Frota 1978:3). 
Em sua abordagem psicológica de nove artistas populares, Frota (1978:3) trabalha com as histórias de vida e motivações de cada artista:

o artista popular desconhece implicações de autoria e gratuidade em arte, conforme a entendemos. $\mathrm{O}$ 'primitivo' proveniente em geral de estratos populares olha com uma visão altamente pessoal através da cultura que recebeu.

A diferença básica, para Lélia Frota entre o artista primitivo e o artista erudito seria o fato de o último ter um "conceito intelectual de arte e da natureza, formado por valores elitistas da civilização ocidental” (Frota 1978:6), qualificando, assim, este artista como 'marginal', tal como definido por Evertt V. Stonequist ${ }^{7}$ (apud Frota 1978:3), que revela a ambiguidade e a liminaridade de estar entre duas normas. Algo que o aproxima da ideia de bricoleur, utilizada por Lévi-Strauss para abordar o mecanismo de pensamento mitopoético:

subsiste entre nós uma forma de atividade que, no plano técnico, permite conceber perfeitamente aquilo que, no plano da especulação, pode ser uma ciência que preferimos antes chamar de 'primeira' mais que de primitiva: é aquela comumente designada pelo termo bricolage (Lévi-Strauss 2008:32).

Embora Frota (1978) não cite o termo bricoleur, encontra, na noção de mitopoética, a chave analítica para abordar este universo artístico, considerado, aos olhos do mundo ocidental, "ingênuo" e "bruto":

\begin{abstract}
Essa empatia criadora para o confronto de comportamento que nos parecem inéditos, mas que na realidade complementam o nosso, como o espaço que passa a existir do outro lado de uma linha que traçamos, é constantemente reivindicada por Claude Lévi-Strauss, não apenas para a reconceituação e recuperação, para nós, das sociedades sem história, mas também para que reintegremos elementos das sociedades industriais urbanas, onde ele denomina de mitopoético o caso exemplar da arquitetura de Ferdinand Cheval (18361934) em Hauterives, França. LéviStrauss, citando Jaques Lacan, defende também uma revisão de nossa atitude em relação aos internos psiquiátricos, aplicado a toda arte marginalizada, onde se escreve a dos primitivos (Frota 1978:6).
\end{abstract}

Lévi-Strauss procura ressaltar a relação entre atividade técnica e a operação mental - o bricolage intelectual -, produzida no processo de elaboração de artefatos. O personagem conceitual do bricoleur tornou-se fundamental na história da antropologia para se produzir e afirmar os conhecimentos com base em uma relação de alteridade que se proponha não etnocêntrica ou simétrica:

o bricoler é aquele que trabalha com as mãos, utilizando meios indiretos se comparados com os do artista. Ora, a característica do pensamento mítico é a

7 Stonequist, E. V. 1937. The marginal man. New York: C. Secribner's sons. 
expressão auxiliada por repertório cuja composição é heteróclita e que, mesmo sendo extenso, permanece limitado, entretanto, é necessário que o utilize qualquer que seja a tarefa proposta, pois nada mais tem à mão. Ele se apresenta, assim como uma espécie de bricolage intelectual, o que explica relações que se observam entre ambos (Lévi-Strauss 2008:32).

A relação entre o bricoler e o pensamento mítico se apoia na própria ideia de "mitopoética", exigindo da mente do "engenheiro" um alargamento dos conceitos através da diversificação dos signos, das percepções classificatórias e da imersão a uma ordenação "selvagem" do pensamento. Uma ciência selvagem "horizontalmente" constituída por meio do conhecimento de uma "alteridade radical" (Peirano 1995) em relação ao pensamento racionalista e positivista com o qual a antropologia francesa moderna se debatia. O signo seria o elo concreto entre a imagem e o conceito, com a diferença de que o conceito é ilimitado, enquanto o signo é limitado. Lévi-Strauss (2008:32) procura mostrar como o conjunto de elementos da reflexão mítica encontrase situado a "meio caminho entre os perceptos e os conceitos". A mitopoética é entendida aqui como meio produtivo de compreender uma técnica como vínculo para um sistema de pensamento. A nota esclarecedora dos tradutores da primeira edição brasileira de "O pensamento selvagem" demonstra a relevância do uso da palavra francesa bricoler.

$$
\begin{aligned}
& \text { [...] para melhor acompanhar o } \\
& \text { autor em suas considerações sobre o } \\
& \text { pensamento mítico, mantivemos na } \\
& \text { tradução os termos bricoler, bricoleur }
\end{aligned}
$$

\begin{abstract}
e bricolage que, no seu sentido atual, exemplificam com grande felicidade o modus operandi da reflexão mitopoética. O bricoleur é o que executa um trabalho usando meios e expedientes que denunciam a ausência de um plano pré-concebido e se afastam dos processos e normas adotados pela técnica. Caracteriza-o especialmente o fato de operar com materiais fragmentários já elaborados, ao contrário, por exemplo, do engenheiro que, para dar execução ao seu trabalho, necessita da matéria-prima (LéviStrauss 2008:32).
\end{abstract}

Podemos dizer que uma semelhança primordial entre as obras de Lélia Coelho Frota e Edson Meirelles consiste na utilização da noção de mitopoética associada à "palavra primitiva com a sua carga positiva" (Frota 1978:4), de modo a qualificar as respectivas "artes" de que estão tratando, criando conexões com a abordagem que Lévi-Strauss apresenta em "O pensamento selvagem" e, posteriormente, nas "Mitológicas” (LéviStrauss 2004a, 2004b).

Meirelles aponta o anonimato das obras populares como "um divisor de águas" em relação ao design erudito. Acredito que a argumentação está, aqui, em continuidade com a obra fotográfica produzida no âmbito do "Projeto Mafuá". Diferentemente do trabalho de Lélia Coelho Frota, Meirelles privilegia o aspecto não autoral (com raras exceções) dos trabalhos dos quais se ocupou em documentar, criando um registro gráfico numeroso e inédito de uma obra que apresenta a pretensão de um 
enquadramento "coletivo" e que informa também sobre uma noção de "brasilidade" (Figura 5).

\section{CONSIDERAÇÕES FINAIS}

O que o "Projeto Mafuá" e o seu autor delimitam como arte gráfica popular brasileira constitui-se como uma relação de alteridade, uma "categoria de volta", nos termos de Carneiro da Cunha (2009), já que propõe uma questão política para os especialistas do "mundo da arte" (Becker 1977) ou, mais especificamente, para "o mundo da arte popular brasileira" (Mascelani 2002). A proposta do fotógrafo apresenta uma crítica feroz ao não reconhecimento (e consequente "não patrimonialização") do objeto de sua pesquisa - "a pintura e o design popular brasileiro" -, que não tem seu lugar garantido nos museus e publicações brasileiros. Retomando trecho dele que consta no Anexo 3:
Provavelmente seja esta a razão de continuarmos, teimosamente, a ignorar o significado da expressão "arte popular" e sua legitimidade, procurando, com definições sofisticadas, mascarar a expressão artística do homem do povo, depositário de uma arte que foi depurada pela crítica maior dos séculos. Desta forma, o "design popular", esse nosso bem ignorado, continuará expressando o seu apuramento no cerne da nossa cultura nacional, a partir da matéria-prima e tesouro único das culturas: a sensibilidade do artista anônimo (Meirelles 2001:s/p).

O autodidatismo antropológico de Meirelles, sua "antropologia sem métier", é estruturalmente
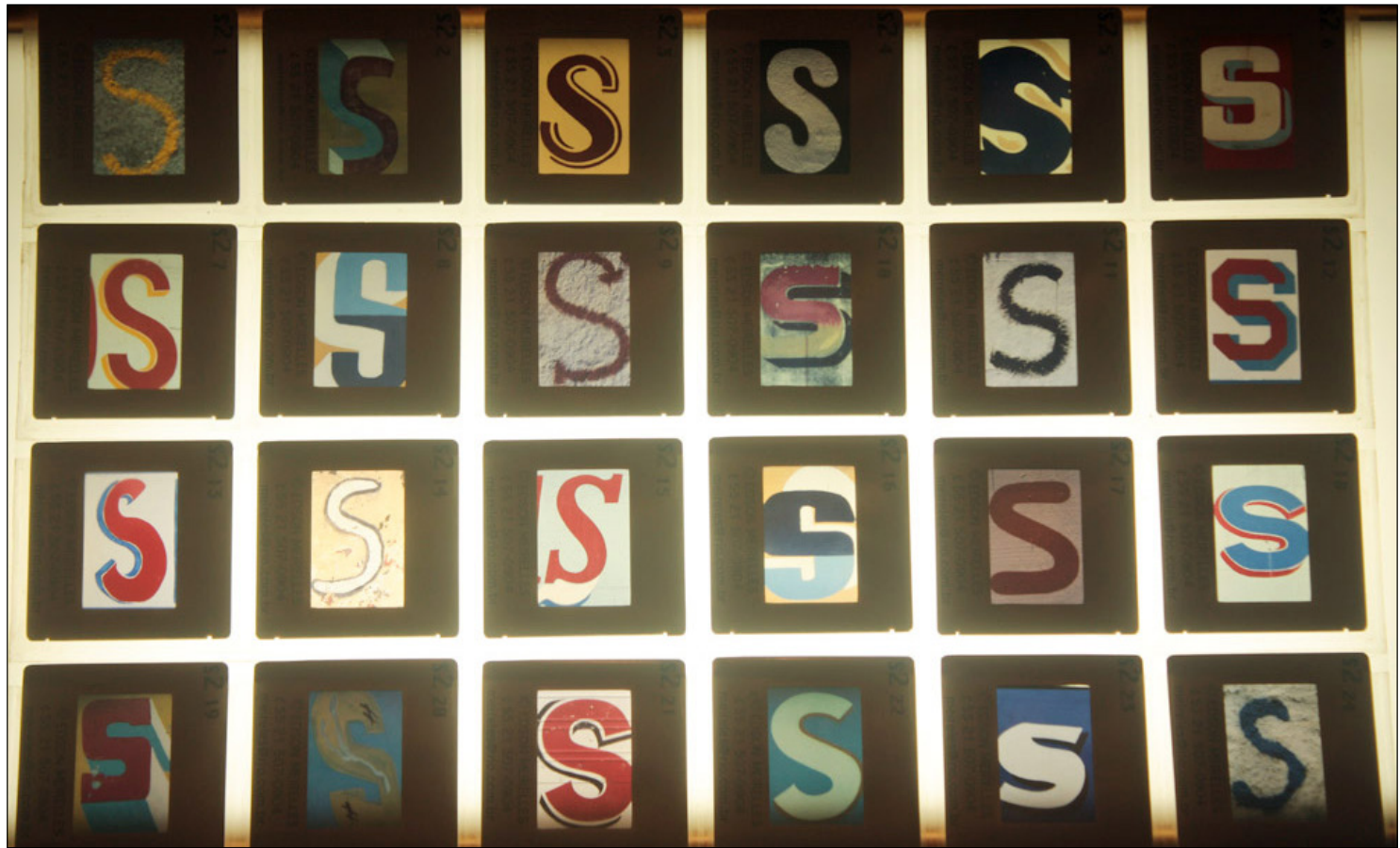

Figura 5 - Os cromos de Edson Meirelles: cartela da coleção “Tipografia popular”, diversas fontes da letra S. Foto: Suiá Omim (2011). 
homóloga ao autodidatismo dos produtores de arte gráfica popular brasileira. Se é possível fazer uma rotação de perspectiva em relação à noção de arte, ou de poder e política, ou mesmo de razão, por que não o fazer com a própria ideia de antropologia? Por que não tornar positiva também a falta de um suposto rigor científico presente na antropologia feita por Meirelles? A ideia é aplicar a torção de perspectivas realizada pelo autor para as noções de arte e design popular, também para a forma como ele constitui coleções e produz antropologias com elas e a partir delas. É essa antropologia que, segundo Viveiros de Castro (2015:20), "está pronta para assumir integralmente sua verdadeira missão, a de ser uma teoria prática da descolonização permanente do pensamento".

\section{AGRADECIMENTOS}

Gostaria de agradecer a Edson Meirelles, pela generosidade de me permitir livre acesso ao seu precioso acervo de pesquisa. Agradeço também a André Demarchi e Marco Antonio Gonçalves, pelas leituras e pelos comentários a este texto.

\section{REFERÊNCIAS}

Abreu, R. 2009. Tesouros humanos vivos ou quando as pessoas tornam-se patrimônio cultural - notas sobre a experiência francesa do Mestre da Arte, in Memória e patrimônio: ensaios contemporâneos. Organizado por R. Abreu \& M. Chagas, pp. 83-96. Rio de Janeiro: Lamparina.

Anastassakis, Z. 2011. Triunfos e impasses: Lina Bo Bardi, Aloísio Magalhães e a institucionalização do design no Brasil. Tese de Doutorado, Departamento de
Antropologia Social, Museu Nacional, Universidade Federal do Rio de Janeiro, Rio de Janeiro.

Andrade, M. 1991. Cartas de Mário de Andrade a Luis Câmara Cascudo. Belo Horizonte: Ed. Vila Rica.

Azevedo, A. s/d. O cortiço. São Paulo: Círculo do Livro.

Bateson, G., e M. Mead. 1987. Balinese character: a photographic analysis. New York: The New York Academy of Sciences.

Bateson, G. 2000 [1972]. Steps to an Ecology of mind. Chicago: The University of Chicago Press.

Becker, H. S. 1977. Mundos artísticos e tipos sociais, in Arte e sociedade: ensaios de sociologia da arte. Organizado por G. Velho, pp. 9-26. Rio de Janeiro: Zahar.

Benjamin, W. 1994. Magia e técnica, arte e política: ensaios sobre literatura e história da cultura. Tradução Sérgio Paulo Rouanet. 7. ed. São Paulo: Brasiliense. (Obras escolhidas v. 1).

Borges, A. 2000. Um caçador de letras. Gazeta Mercantil. São Paulo. 23/06/2000.

Borges, A. 2011. Design + artesanato: o caminho brasileiro. São Paulo: Editora Terceiro Nome.

Caiuby Novaes, S. 2005. O uso da imagem na Antropologia, in $O$ fotográfico. Organizado por E. Samain, pp. 107-115. 2. ed. São Paulo: Hucitec e SENAC.

Cardoso, R. 2004. Tudo é moderno; nada é Brasil: designe a busca de uma identidade nacional, in Tudo 
é Brasil. Organizado por L. Cavalcanti, pp. 81-91. São Paulo: Itaú Cultural; Rio de Janeiro: Paço Imperial.

Cardoso, R. 2005. O design brasileiro antes do design. São Paulo: Cosac Naify.

Carneiro da Cunha, M. 2009. Cultura com aspas e outros ensaios. São Paulo: Cosac Naify.

Carnicel, A. 1998. O olho etnográfico de Mário de Andrade, in O fotográfico. Organizado por E. Samain, pp. 169-176. São Paulo: Ed. Hucitec.

Clastres, P. 1978. A sociedade contra o Estado: pesquisas de antropologia política. Rio de Janeiro: F. Alves.

Clifford,J.1998. A experiência etnográfica: Antropologia e Literatura no século XX. Rio de Janeiro: UFRJ.

Coelho, F. 2010. Livro ou livro-me: escritos babilônicos de Hélio Oiticica (1971-1978). Rio de Janeiro: UERJ.

Cunha, O. M. G. 2004. Tempo imperfeito: etnografia do arquivo. Mana 10(2):287-322.

Demarchi, A. 2014. Kukràdjà Nhipêjx/Fazendo cultura: beleza, ritual e políticas da visualidade entre os Mebêngôkre - Kayapó. Tese de Doutorado, Departamento de Antropologia Cultural, Universidade Federal do Rio de Janeiro, Rio de Janeiro.

Freire, M. 2006. Gregory Bateson, Margaret Mead e o caráter balinês. Notas sobre os procedimentos de observação fotográfica em
Balinese Character. A Photographic Analysis. ALCEU 7(13):60-72.

Frota, L. C. 1978. Mitopoética de 9 artistas brasileiros. Rio de Janeiro: FUNARTE.

Geiger, A. 1999. Uma antropologia sem métier. primitivismo e crítica cultural no modernismo brasileiro. Tese de Doutorado, Departamento de Antropologia Social, Museu Nacional, Universidade Federal do Rio de Janeiro, Rio de Janeiro.

Ginzburg, C. 1989. Mitos, emblemas e sinais: morfologia e história. São Paulo: Cia. das Letras.

Gonçalves, J. R. S. 2007. Antropologia dos objetos: coleções, museus e patrimônios. Rio de Janeiro: IPHAN.

Gonçalves, M. A. s/d. O mundo poético do cordel. Mimeo.

Ingold, T. 2000. The perception of the environment: essays in livelihood, dwelling, and skill. London: Routledge.

Lagrou, E. 2008. A arte do Outro no surrealismo e hoje? Horizontes Antropológicos 14(29):217230. DOI: http://dx.doi.org/10.1590/S010471832008000100009 .

Lagrou, E. 2009, Arte indígena no Brasil: agência, alteridade e relação. Belo Horizonte: C/Arte.

Lagrou, E. 2011. Existiria uma arte das sociedades contra o Estado? Revista de Antropologia 54(2):747-780. DOI:https://doi.org/10.11606/2179-0892.ra.2011.39645. 
Lessa, W. D. 1994. A ESDI e a contextualização do design. Piracema 2(2):102-107.

Lévi-Strauss, C. 2004a. O cru e o cozido. Mitológicas 1. São Paulo: CosacNaify.

Lévi-Strauss, C. 2004b. Do mel às cinzas. Mitológicas 2. São Paulo: CosacNaify.

Lévi-Strauss, C. 2008. O pensamento selvagem. Campinas: Papirus.

Mascelani, A. 2002. O mundo da arte popular brasileira. Rio de Janeiro: Museu Casa do Pontal; Mauad Editora.

Mascelani, A. 2011. O Brasil na arte popular. Rio de Janeiro: Museu Casa do Pontal.

Meirelles, E. 2001. Pesquisa a 'Pintura Popular Brasileira'. Mimeo. s/p.

Meirelles, E. 2003. Lentes abertas à expressão popular. Revista Abrigraf(205):56-58.

Omim, S. 2015. Acervo Mafuá: notas etnográficas sobre três coleções de pintura e design popular no Brasil. Museologia e Patrimônio 8(1):53-77.

Omim, S. 2016. Acervo Mafuá: uma etnografia da pintura e do design popular na obra fotográfica de Edson Meirelles. Tese de Doutorado, Departamento de Antropologia Cultural, Universidade Federal do Rio de Janeiro, Rio de Janeiro.
Peirano, M. 1995. A favor da etnografia. Rio de Janeiro: Relume-Dumará.

Risério, A. 1995. Avant-garde na Bahia. São Paulo: Instituto Lina Bo e P. M. Bardi.

Santiago, S. 1982. Vale quanto pesa: ensaios sobre questões político-culturais. Rio de Janeiro: Paz e Terra.

Sontag, S. 2004. Sobre a fotografia. São Paulo: Cia. das Letras.

Souza, P. L. P. 1996. ESDI: biografia de uma ideia. Rio de Janeiro: EDUERJ.

Souza Leite, J. 2006. De costas para o Brasil, o ensino de um design internacionalista, in $O$ design gráfico brasileiro - anos 60. Organizado por C. H. Melo, pp. 252-283. São Paulo: Cosac \& Naify.

Strathern, M. 1987. The limits of auto-anthropology, in Anthropology at home. Editado por A. Jackson, pp. 59-67. London: Tavistock.

Strathern, M. 2013. Fora de contexto: as ficções persuasivas da antropologia. São Paulo: Terceiro Nome.

Velho, G. 2011. Lélia Coelho Frota: pioneira e mediadora, in Catalogo da $15^{\circ}$ Mostra do Filme Etnográfico. Rio de Janeiro: Interior Produções.

Viveiros de Castro, E., e R. Sztutman. 2008. Encontros: Eduardo Viveiros de Castro. 1. ed. v. 1. Rio de Janeiro: Azougue Editorial. 
Viveiros de Castro, E. 2015. Metafísicas canibais. Wagner, R. 2010. A invenção da cultura. São Paulo: São Paulo: Cosac Naify \& n-1 Edições. Cosac Naify. 


\section{ANEXO 1 - A arte gráfica brasileira. Fonte: Meirelles (2001:s/p).}

Nos muitos variados estudos e classificações do design e dos alfabetos, existe uma infinidade de critérios para defini-los e sistematizá-los, normalmente escapam da ótica dos estudiosos os alfabetos e o design de origem popular. Esta questão, a do reconhecimento das manifestações artísticas oriundas das camadas menos cultas da sociedade, não é nova, como também não é nova a questão da busca da nossa identidade cultural, da autenticidade de nossa arte. A questão do nacional, do autêntico, da brasilidade, constitui até hoje, às vésperas de completar quinhentos anos do descobrimento, a preocupação de uma considerável parcela da intelectualidade brasileira. Porém, quando estas manifestações emanam das camadas mais cultas da sociedade, como a arte erudita, este reconhecimento é mais fácil e imediato, pois continuamos mantendo as velhas relações que predominavam no Brasil-colônia, onde a cultura era um traço exclusivo da classe dominante. Nosso design, se assim o pudéssemos [sic] chamálo no princípio do século passado, era produzido para um mercado restrito aos centros coloniais mais importantes - Minas Gerais, Bahia, Pernambuco e Rio de Janeiro -, onde a igreja pontificava como seu maior e quase que exclusivo consumidor, e era a esse tempo, considerado arte menor. Arte menor porque os artistas, pintores e escultores, entalhadores eram, na sua maioria, brasileiros autodidatas e sem formação técnica, escravos, negros libertos e mulatos. Sua expressão artística era calcada em valores metropolitanos, onde as estampas e gravuras religiosas, geralmente espanholas, alemãs e italianas, eram a grande mestra. Esse design, embora não correspondesse a uma estética faustosa e de ostentação, tão característica do clero e das classes dominantes da época, influenciando, ainda, na técnica e na expressão, pelos maneirismos barrocos que nos chegavam da Europa, destacou diversos artistas de origem popular, alguns de qualidades excepcionais. Antonio da Silva Lisboa - o Aleijadinho -, sem sombra de dúvida, o maior expoente deste período, arquiteto designer, artista plástico, escultor, entalhador, o mestre da pedra sabão, Valentin Fonseca e Silva - o Mestre Valentin, designer e entalhador, Mestre Ataíde e tantos outros, que, sob a influência decisiva do barroco, buscavam já a renovação de velhos modelos metropolitanos. Podemos considerar este período, para as artes plástica brasileiras, as primeiras tentativas de um design com uma correspondência entre forma e conteúdo, que nos aproximasse de uma estética nacional, notadamente no movimento das formas, no uso intenso das cores e fundamentalmente na expressão exuberante do sentimento. Todo desenvolvimento, estilístico, e suas consequentes manifestações estéticas do design brasileiro, foi interrompido com a chegada da Missão Artística Francesa em 1816. Mandada buscar por D. João VI, era encabeçada por Joaquim Montigny, que juntamente com outros vão construir o corpo docente da Academia de Belas Artes. Formada de figuras ilustres da arte europeia da época, neoclássicos ou acadêmicos todos produzem aqui uma arte transplantada, estilizada, inautêntica. Embora a arte alcance agora o status de arte legitimada, pois erudita, esta deixa para bem mais tarde para ser reconhecida como arte tipicamente brasileira, pois o que vai dar a procurada autenticidade da nossa arte e do nosso design não será certamente o conteúdo, tema ou assunto, e sim o sentimento de brasilidade que nos vem da forma e das cores. 
ANEXO 2 - A arte popular. Fonte: Meirelles (2001:s/p).

A arte comporta em si as mais diversas manifestações do homem. Ao criar, o artista não utiliza apenas a inteligência, a sensibilidade ou mesmo suas habilidades. O seu "saber" e o seu "fazer" estão ligados ao meio cultural e à comunidade. Em nenhuma expressão de arte a manifestação do coletivo é tão evidente como na arte popular, na qual a influência do meio se revela não somente de forma material, mas definitivamente, de forma psicológica. $\mathrm{O}$ artista popular não é, a rigor, um criador individual, uma vez que se encontra imerso no ambiente que determina sua própria individualidade. Quando, em desenvolvimento do seu processo artístico, seu espírito criador acaba entrando em comunhão com o absoluto, fonte primacial de toda a criação, onde o resultado formal da sua obra é o fruto do seu labor, sem dúvida, mas a sua criação pertence ao coletivo: "as mãos são do artista, a criação é da coletividade”. Ao exprimir esse sentimento, $\mathrm{o}$ artista popular manifesta não as influências eruditas, intelectuais ou escolarizadas e sim a temática, as cores e as formas de sua gente. Ele manifesta através da sua sensibilidade, uma identidade coletiva, refletindo através de sua arte, uma arte de todos - dos que praticam e dos que assimilam. Uma arte do povo e não para ele. E podemos, assim, perceber o tipo de arte de cada grupo cultural ou de cada região, onde a expressão tem uma identidade comum, porém feita com mãos diferentes. O popular urbano, recebendo influência exterior através dos modernos meios de comunicação, por maior que sejam os seus apelos e seduções, continua popular. Diferente do popular rural, muito mais fechado em si e isolado no seu dia a dia, ambos sentindo, porém, lenta e inexoravelmente, o impacto das novas tecnologias. Assim, o homem do povo vai dando vazão à sua sensibilidade, e expressando a sua beleza com sua arte espontânea e simbólica, provando que, não importa o estágio evolutivo de sua cultura, ele é um animal que cria. 
ANEXO 3 - A arte gráfica popular brasileira. Fonte: Meirelles (2001:s/p).

A arte gráfica popular brasileira, esta estética tão nossa, quanto ignorada, normalmente, é encontrada em rótulos de bebidas, garrafadas e unguentos, em portas de circos e shows de ilusionismo, em reclames comerciais, em barracas, placas, cartazes e carrocinhas de ambulantes, enfim, em todas as possíveis expressões da arte gráfica do artista popular, pelos confins do Brasil. A beleza de sua representação plástica manifesta-se de maneira distinta, combinando ou isolando entre si o ritmo de cores, das formas e do movimento.

$\mathrm{O}$ artista gráfico popular exprime o seu sentimento estético sem regras e sem barreiras, e o resultado é um "design" despido de tecnicismo conceitual, em que espaço e profundidade, altura e largura, não têm a mínima importância, pois expressa com emoção e sentimento uma obra extremamente pessoal. O que vale é a emoção e o sentimento, já que estamos falando de uma obra extremamente pessoal. De caráter puro, ingênuo, e algumas vezes irracional, sua maior característica é o anonimato, espécie de divisor de águas ante o design erudito.

O artista gráfico popular é invariavelmente dotado de uma intuitiva sabedoria plástica, que se manifesta em contraposição à sua ausência de técnica e, ao mesmo tempo, dá suporte tão característico aos autodidatas, nos quais se destaca o elementarismo das cores quase sempre puras, o senso decorativo, a expressiva simplicidade do desenho e a originalidade do traço. Além da exuberância das cores, da coerência entre forma e conteúdo, há que se ressaltar as particularidades linguísticas e o lirismo mesmo, na interpretação de sua mensagem, quando o design se encontra acompanhado de um texto. Um design espontâneo e ausente de intelectualismo, que procura transmitir sua mensagem com a maior fidelidade possível.

Detalhista, pois a gente do povo trabalha sempre com cuidado e paciência, o artista gráfico popular não respeita nem o tempo nem o espaço, e sua lógica, longe de ser realista, busca interpretar seus sentimentos. A ausência de técnica acaba transformando-se na maior qualidade de sua obra, pois, não conseguindo transmitir exatamente o que sente e o que vê, recorre à sensibilidade para realizála, não sendo exagero afirmar que, quanto menos perfeita sua técnica, mais pleno seu sentido artístico. Sua ampla liberdade de criar e gerar uma obra livre da pressão e padronização formais. O padrão é sempre do povo, enquanto o estilo é do artista. Cada região ou grupo cultural tem sua técnica, sua maneira de comunicação. A arte gráfica regional, que pode se caracterizar de diversas maneiras, revela o sabor pitoresco das tradições, usos e costumes locais. Mas é definitivamente na expressão das cores que o design popular se manifesta de forma mais autêntica e seminal. O vermelho pleno, pintado na tabuleta de um bar em Belém, será diferente quando utilizado por um artista para pintar uma carranca, nas barrancas do Rio São Francisco, na Bahia. O amarelo espiga de milho antropomórfica, pintada numa carrocinha de ambulante no interior de Minas Gerais, não terá o mesmo brilho e intensidade do amarelo usado no cartaz de uma loja na zona rural em Santa Catarina.

$\mathrm{O}$ "design" popular desconhece a técnica acadêmica escolarizada, a artificialidade, e apresenta-se quase sempre de forma não decodificável por elementos alheios à sua 
realidade socioeconômica-cultural, sendo por isso interpretado como rudimentar e imperfeito, enfim, uma expressão artística de má qualidade e desprovida de valor documental. Sem dúvida, essa interpretação se deve ao fato de a palavra "popular", de conotação pejorativa, estar associada à produção vulgar, pobre e sem valor, traduzindo, desta forma, as velhas rejeições tão características das ideias aristocráticas, de desprezo de tudo que é do povo. Provavelmente seja esta a razão de continuarmos, teimosamente, a ignorar o significado da expressão "arte popular" e sua legitimidade, procurando, com definições sofisticadas, mascarar a expressão artística do homem do povo, depositário de uma arte que foi depurada pela crítica maior dos séculos. Desta forma, o "design popular", esse nosso bem ignorado, continuará expressando o seu apuramento no cerne da nossa cultura nacional, a partir da matéria-prima e do tesouro único das culturas: a sensibilidade do artista anônimo. 